ISSN : 1412-7601

Volume 3, No.2 September 2017

http://www.ekonobis.unram.ac.id

EKONOBIS

\title{
Indeks Kedalaman dan Keparahan Kemiskinan di Provinsi Nusa Tenggara Barat dan Penanganannya Dalam Ekonomi Islam
}

\author{
M.Irwan \\ Universitas Mataram
}

\begin{tabular}{|c|c|}
\hline ARTICLE INFO & Received : 29 Juli 2017; Accepted: 23 Agustus 2017; Published: September 2017 \\
\hline $\begin{array}{l}\text { Keywords: } \\
\text { Index of Depth, Severity, } \\
\text { Poverty Line, Zakat }\end{array}$ & $\begin{array}{l}\text { ABSTRACT : This study aims to determine: Number of Population classified as poor, Depth } \\
\text { Index and Poverty Severity in West Nusa Tenggara Province and Handling in Islamic } \\
\text { Economy. The research method used is descriptive method, the data used secondary data } \\
\text { and analysis tools used is the technique of growth analysis. } \\
\text { The results showed that the condition of poverty in West Nusa Tenggara is seen from the } \\
\text { number of population decreased with negative growth average } 3,19 \text { percent. Percentage } \\
\text { of population in } 2016 \text { amounted to } 16.02 \text { percent. Rural poor are } 14.82 \text { percent and } 17.55 \\
\text { percent for urban areas by } 2016 \text {. The poverty line for the urban poor is Rp } 346,581 \text { while } \\
\text { for rural areas Rp } 328,775,- \text { by } 2016 \text {. Depth Index (P1) poverty in NTB in } 2016 \text { of } 2,626 \\
\text { indicating that the economic conditions of the poor are in an improved condition. The } \\
\text { Poverty Severity Index (P2) in NTB in } 2016 \text { is } 0.653 \text { in } 2016 \text { which indicates the inequality } \\
\text { of expenditure of the poor is narrowed. Poverty alleviation in Islam can be done one of } \\
\text { them through zakat command. Baznas West Nusa Tenggara Province has been able to } \\
\text { raise funds Zakat, Infaq and Shadaqah (ZIS) and contribute in poverty alleviation in West } \\
\text { Nusa Tenggara. The amount of ZIS funds collected in } 2016 \text { reached Rp } 8,288,499,700,- \\
\text { from the target of Rp 7.500.000.000,-. }\end{array}$ \\
\hline $\begin{array}{l}\text { Kata Kunci: } \\
\text { Indeks Kedalaman, } \\
\text { Keparahan, Garis } \\
\text { Kemiskinan, Zakat. }\end{array}$ & $\begin{array}{l}\text { ABSTRAK : Penelitian ini bertujuan untuk mengetahui : Jumlah Penduduk yang tergolong } \\
\text { miskin, Indeks Kedalaman dan Keparahan Kemiskinan di Provinsi Nusa Tenggara Barat dan } \\
\text { Penanganannya Dalam Ekonomi Islam. Metode Penelitian yang dipergunakan adalah } \\
\text { metode deskriptif, data yang dipergunakan data sekunder dan alat analisis yang } \\
\text { dipergunakan adalah teknik analisis pertumbuhan. Hasil penelitian menunjukkan bahwa } \\
\text { Kondisi kemiskinan di Nusa Tenggara Barat dilihat dari jumlah penduduk mengalami } \\
\text { penurunan dengan rata-rata pertumbuhan negatif 3,19 persen. Persentase penduduk } \\
\text { pada tahun } 2016 \text { sebesar } 16,02 \text { persen. Penduduk miskin di daerah pedesaan sebesar } \\
14,82 \text { persen dan } 17,55 \text { persen untuk daerah perkotaan pada tahun 2016. Garis } \\
\text { kemiskinan untuk penduduk miskin di daerah perkotaan Rp } 346.581 \text { sedangkan untuk di } \\
\text { daerah pedesaan Rp } 328.775,- \text { pada tahun } 2016 \text {. Indeks Kedalaman (P1) kemiskinan di } \\
\text { NTB pada tahun } 2016 \text { sebesar } 2,626 \text { yang menunjukkan bahwa kondisi perekonomian } \\
\text { penduduk miskin berada dalam kondisi yang membaik. Indeks Keparahan Kemiskinan (P2) } \\
\text { di NTB pada tahun } 2016 \text { sebesar } 0,653 \text { pada tahun } 2016 \text { yang menunjukkan ketimpangan } \\
\text { pengeluaran penduduk miskin semakin menyempit. Pengentasan kemiskinan dalam Islam } \\
\text { dapat dilakukan salah satunya melalui perintah zakat. Baznas Provinsi Nusa Tenggara } \\
\text { Barat telah mampu menghimpun dana Zakat, Infaq dan Shadaqah (ZIS) dan berkontribusi } \\
\text { dalam pengentasan kemiskinan di Nusa Tenggara Barat. Jumlah dana ZIS yang berhasil } \\
\text { dihimpun pada tahun } 2016 \text { mencapai Rp } 8.288 .499 .700,- \text { dari target sebesar Rp } \\
\text { 7.500.000.000,- }\end{array}$ \\
\hline
\end{tabular}

Corresponding Author:

Alamat : Program Studi Ekonomi Pembangunan, Fakultas Ekonomi dan Bisnis, Universitas Mataram, Jln. Majapahit No. 62 Mataram.

e-mail: dae_irwan@unram.ac.id 


\section{PENDAHULUAN}

\section{Latar Belakang}

Kemiskinan merupakan sebuah fenomena yang mendunia, setiap negara memiliki karakteristik kemiskinannya masing masing yang dapat diakibatkan oleh banyak sebab seperti geografis, kultur, sistem pemerintahan dan lainnya (Stamboel, 2012). Bervariasinya faktor yang menjadi penyebab kemiskinan, mengakibatkan bervariasi pula sistem dan cara penanganan penduduk supaya lepas dari kemikskinan. Bentuk - bentuk penangan penduduk miskin sangat tergantung pada kemampuan, kondisi serta karakteristik dari negara - negara penyandang kemiskinan. Yang tidak kalah pentingnya adalah penanganan kemiskinan sangat bergantung dari makna, definisi, ciri dan indikator atau karakteristik kemiskinan itu sendiri.

Kebijakan pengentasan kemiskinan diarahkan untuk memberikan peluang yang seluas-luasnya kepada penduduk miskin agar dapat meningkatkan kualitas hidupnya, baik melalui paket-paket kebijakan pemerintah maupun melalui usaha-usaha yang dilakukan oleh pemerhati masalah kemiskinan. Implementasi dari paket-paket kebijakan berkaitan dengan kemiskinan satu sisi menunjukkan hasil yang menggembirakan. Hal ini ditandai dengan semakin berkurangnya jumlah penduduk miskin , dari 37,17 juta jiwa $(16,58 \%)$ pada tahun 2007 menjadi 27,77 juta jiwa $(10,70 \%)$ pada tahun 2016 (BPS,2017). Namun, keberhasilan tersebut tidak serta merta disambut dengan kepuasan yang berlebihan, karena masih banyak saudara sebangsa yang masih berkuat dengan kemiskinan.

Penduduk miskin tersebar di daerah perkotaan maupun pedesaan. Di daerah pedesaan, mereka mengandalkan kehidupannya pada sektor pertanian dan kepemilikan lahan yang sangat kecil atau disebut petani gurem/subsisten. Penduduk miskin yang berada di daerah perkotaan, merupakan akibat dari proses urbanisasi yang cukup masif dari penduduk miskin desa yang pindah ke kot untuk mencari pekerjaan. Kemiskinan tidak hanya dilihat dari aspek material semata, namun harus diperhatikan juga pada aspek - aspek kemiskinan lainnya baik dari aspek kesehatan, pendidikan dan lainnya. Dengan demikian, Indonesia masih dihadapkan dengan kemiskinan yang bersifat multidimensial (Stamboel, 2012).

Seluruh sistim ekonomi baik sistim ekonomi konvensional terlebih ekonomi Islam, sangat memperhatikan masalah kemiskinan. Kemiskinan merupakan permasalahan yang dihadapi sejak jaman dahulu terutama berkaitan dengan pemenuhan kebutuhan. Berkenaan dengan hal itu, ekonomi islam yang bersandar pada Al-Qur'an Al-Hadist dan ljtihad. Islam memerintahkan orang-orang kaya untuk membantu orang miskin agar kekayaan tidak menumpuk pada di antara orang kaya saja (Al-Hasyr,7). Ekonomi Islam memiliki perbedaan pandangan tentang kemiskinan dengan ekonomi konvensional. Jika ekonomi konvensional melihat kemiskinan hanya dari aspek material, justru ekonomi Islam melihat kemiskinan dari aspek material dan spiritual sekaligus. Ekonomi Islam berpegang pada tujuan mendasar yaitu menghantarkan manusia untuk mencapai al-falah yaitu kemenangan (kebahagiaan) hakiki baik di dunia maupun di akhirat.

Pengentasan kemiskinan dalam Islam bisa dilaksanakan secara individu dan lebih ditekankan secara kelembagaan yang diatur oleh pemerintah. Kemiskinan dalam pandangan Islam merupakan suatu ancaman yang sangat membahayakan keberlangsunagan kehidupan manusia baik secara individu maupun masyarakat, akidah maupun iman serta akhlak maupun moral. la juga membahayakan pemikiran, kebudayaan, keluarga dan umat (Qardhawi, 1995). Menurut Sa'ad (2007), Kemiskinan merupakan sesuatu yang yang sama tuanya denganusia kemanusiaan itu sendiri, implikasi permasalahannya dapat melibatkan seluruh ospek kehidupan manusia. Kemiskinan merupakan perwujudan dari hasil interaksi yang melibatkan hampir semua aspek yang dipunyai manusia dalam kehidupannya. Menurut Al-Ghazali yang dikutip Wargadinata (2011), kemiskinan adalah sebab juga akibat 
dalam waktu yang sama, yang merupakan serial kesengsaraan yang menimpa kita semua.

Kebijakan pengentasan penduduk dari kemiskinan juga dilakukan oleh Pemerintah provinsi Nusa Tenggara Bara (NTB)t. Capaian penurunan penduduk miskin di NTB menunjukkan hasil yang menggembirakan. Jumlah penduduk miskin tahun 2007 mencapai 1.118 .600 jiwa $(24,99 \%)$ turun menjadi 786,580 jiwa $(16,02 \%)$ pada tahun 2016 (BPS NTB,2017). Dengan demikian, selama kurun waktu 10 tahun terjadi penurunan penduduk miskin sebanyak 332.020 jiwa. Kesuksesan menurunkan penduduk miskin ini menyertai berbagai keberhasilan dan prestasi provinsi NTB dalam menata perekonomiannya. Keberhasilan dan berbagai prestasi tersebut diapresiasi positif, meskipun pada saat yang bersamaan masih ada penduduk provinsi NTB dalam perjalanannya, strategi-strategi Islam ini belum secara maksimal dilakukan.

Kemiskinan akan menimbulkan stabilasi ekonomi, keamanan dan sosial budaya terganggu. Kemiskinan akan menghadirkan generasi-genarasi pelanjut estafet pembangunan yang tidak berkualitas. Kemiskinan dapat menipiskan keimanan bahkan akan mengantarkan manusia menjadi manusia yang ingkar, kufur bahkan syirik. Kemiskinan akan menghadirkan kemiskinan yang baru yaitu hadirnya manusia yang memiliki sifat egoistis, individualistis, pelit, kikir, rakus dan tamak. Kemiskinan akan menghadirkan manusia-manusia yang memelas mengharapkan rasa kasihan dari orang lain dan dampak lainnya. Oleh karenanya, masalah kemiskinan harus dicari solusi penganganan yang ampuh dan mujarab dan terarah tepat sasaran, disamping langkah-langkah strategis yang telah berhasil dilakukan oleh pemerintah pada masa lalu maupun pada saat sekarang.

Penelaahan dan analisis tentang kemiskinan yang terjadi di NTB merupakan hal yang sangat penting, merujuk pada data kemiskinan pada tahun-tahun yang lalu hingga tahun berjalan. Hal ini dimaksudkan untuk melihat dan mengetahui keberhasilan provinsi Nusa Tenggara Barat dalam pelaksanaan program-program kemiskinan serta melihat posisi geografis kemiskinan berada. Pada sisi lain, permasalahan kemiskinan yang telah dihadapi masih memfokuskan pada kebijakan dari aspek materi belaka, sementara dari aspek ruhaniah belum tersentuh secara maksimal. Perpaduan dua unsur ini diharapkan akan mampu menurunkan jumlah penduduk miskin.

\section{Rumusan Masalah}

Berdasarkan uraian pada latar belakang di atas, maka dapat disusun rumusan masalah sebagai berikut :

1. Bagaimana kondisi kemiskinan di Nusa Tenggara Barat.

2. Bagaimana indeks kedalaman dan keparahan kemiskinan di Nusa Tenggara Barat.

3. Bagaimana strategi penanganan kemiskinan di Nusa Tenggara Barat dalam ekonomi Islam.

\section{Tujuan dan Manfaat Penelitian Tujuan Penelitian}

Berdasarkan rumusan masalah di atas, maka tujuan penelitian ini adalah umtuk mengetahui :

1. Jumlah penduduk yang tergolong miskin di Provinsi Nusa Tenggara Barat.

2. Indeks kedalaman dan keparahan kemiskinan di Provinsi Nusa Tenggara Barat.

3. Strategi penanganan kemiskinan di Provinsi Nusa Tenggara Barat dalam ekonomi Islam.

\section{Manfaat Penelitian}

Penelitian ini diharapkan sebagai informasi bagi berbagai pihak yang berkomitmen untuk berpihak pada masyarakat miskin, baik pemerintah, lembaga non pemerintah. Hal ini juga tertuju pada simpatisan ekonomi Islam agar dapat mengetahui solusi nyata dari ekonomi Islam tentang strategi tentang penanganan kemiskinan di Nusa Tenggara Barat. 


\section{TINJAUAN PUSTAKA}

\section{Penelitian Sebelumnya}

Hasil kajian yang dilakukan oleh Stamboel (2012) berhasil mengidentifikasi wajah kemiskinan di Indonesia yaitu mayoritas penduduk miskin menggantungkan hidupnya pada sector pertanian, mereka tergolong petani gurem/subsisten, disparitas yang tinggi anata kota dan desa, disparitas yang tinggi antar provinsi, dominasi belanja pada kelompok makanan, berkumpul di sekitar garis kemiskinan dan kemiskinan bersifat multidimensional. Lebih lanjut Stamboel mengatakan bahwa hambatan-hambatan kemiskinan itu disebabkan tekanan struktual yang tidak memihak orang miskin, kurangnya sumberdaya manusia yang berkualitas, kelembagaan yang rapuh dana danya hambatan social dan budaya.

Abd. Majid (2011) mengatakan bahwa penyebab kemiskinan versi Islam karena ketidakmampuan umat Islam mengeksploitasi Sumber Daya Alam (SDA). Karena Allah telah menganugerahkan SDA (nikmat) yang melimpah ruah baik bersumber dari langit, darat bahkan lautan. Dalam hal ini adalah kemampuan ilmu manusialah yang terbatas untuk mengkploitasi SDA yang menyebabkan manusia terperosokdalam kemiskinan. Pada sisi lain penyebab kemiskinan di dunia Islam termasuk di Indonesia adalah dualisme ekonomi, keuangan dan system pasar dan diskriminasi regional. Lebih lanjut Abd.Majid mengutip pendapat Irfan UIHaq (1996) yang menyatakan setidaknya ada delapan penyebab utama kemiskinan menurut Al-Qur'an" yaitu :

1. Disebabkan ketidaktaatn mereka terhadap ajaran Ilahi. Akibat adanya segolomg manusia yang memakan harta anak yatim.

2. Akibat ulah tangan manusia sendiri.

3. Tidak bertanggungjawabnya orang kaya terhadap orang miskin.

4. Keenganan orang kaya menjadikan harta sebagai tujuan hidup.

5. Praktek dikriminasi alokasi hasil eksploitasi SDA oleh golongan manusia terhadap golongan yang lain.
6. Sikap manusia yang malas bekerja dan kebiasaan untuk meminta-minta.

7. Terkonsentrasinya kekuasaan politik dan ekonomi pada golongan tertentu.

8. Pengekploitasian dan penindasan baik dalam aspek politik, social dan ekonomi oleh golongan tertentu atas golongan yang lainnya.

\section{Pengertian Kemiskinan}

Miskin dapat diartikan sebagai ketidakmampuan seseorang atau keluarga dalam memenuhi kebutuhannya. Kebutuhan yang dimaksud mencakup kebutuhan ekonomi, sosial, politik emosional maupun spiritual. Pengertian ini memang terlalu luas dan tidak operasional sehingga sulit diukur (Maipita, 2014). Secara garis besar definisi miskin dapat dipilah menjadi dua aspek, yaitu: (1) aspek primer, yaitu berupa miskin aset (harta), organisasi sosial politik, pengetahuan dan keterampilan; dan (2) aspek sekunder, yaitu berupa miskin terhadap jaringan sosial, sumber sumber keuangan dan informasi (Arsyad, 2010). Kemiskinan menurut Bank dunia adalah berhubungan dengan tempat tinggal, sakit atau tidak mampu untuk melakukan pengobatan ke dokter, tidak mampu menikmati pendidikan (Sekolah), tidak mampu untuk membaca dan menulis (baca-tulis) , tidak memliki pekerjaan sehingga masa depan tidak jelas, tidak memiliki akses akan air bersih, tidak berdaya, kurang nya representasi dan kebebasan. Badan Pusat Statistik (BPS) menggunakan pendekatan pemenuhan Kebutuhan Dasar (basic needs approach) dalam menentukan kemiskinan. Seseorang tergolong dalam kategori miskin bila la tidak mampu memenuhi kebutuhan dasarnya (basic needs), dengan kata lain, kemiskinan dipandang sebagai keditakmampuan dari sisi ekonomi dalam memenuhi kebutuhan dasar, baik makanan maupun non makanan yang di ukur dari sisi pengeluaran.

Marianti dan Munawar (2006) dalam Maipita (2014) berpendapat bahwa kemiskinan merupakan fenomena multidimensi, didefinisikan dan siukur dalam banyak acara. Dalam banyak kasus ,kemiskinan telah diukur dengan 
terminologi kesejahteraan ekonomi, seperti pendapatan dan konsumsi. Seseorang dikatakan miskin apabila la berada dibawah tingkat kejahteraan minimum tertentu yang telah disepakati. Dalam sumber yang sama, Niemietz (2011) menyatakan bahwa kemiskinan adalah ketidak mampuan untuk membeli barang - barang kebutuhan dasar seperti makanan, pakaian, papan dan obatobatan. Kemiskinan lazimnya digambarkan sebagai gejala kurangnya pendapatan untuk memenuhi kebutuhan hidup yang pokok. Sekelompok anggota masyarakat dikatakan dibawah garis kemiskianan jika pendapatan kelompok anggotas masyarakat tidak cukup untuk memnuhi kebutuhan hidup yang paling pokok seperti pangan, pakaian dan tempat tinggal. Garis kemiskinan yang menentukan bats minimum pendapatan yang diperlukan untuk memenuhi kebutuhan pokok dapat dipengaruhi oleh tiga hal yaitu (1) presepsi manusia terhadap kebutuhan yang diperlukan, (2) posisi manusia di dalam lingkungan sekitar, dan (3) kebutuhan objektif manusia untuk dapat hidup secara manusiawi (Setiadi, dkk, 2011).

Berdasarkan pengertian dari kemiskinan dan diuraikan oleh beberapa pakar di atas, tampak adanya perbedaan kajian yang berkaitan dengan seseorang dikatakan miskin. Dari beberapa makna di atas, terlihat penekanannya lebih tertuju pada sisi ekonomi, yaitu ketidakmampuan untuk memenuhi kebutuhan standar minimal, sehingga kehidupan yang layak belum berpihak pada seseorang atau rumah tangga yang tergolong miskin. Penekanan pada sisi ekonomi karena manusia sebagai pelaku ekonomi harus mampu mewujudkan kebutuhan manusia untuk memenuhi kehidupan yang layak merupakan syarat ,minimal untuk menghindari dari julukan si miskin. Pada sisi lain, kemiskinan juga dapat dilihat dari aspek lain seperti rendahnya tingkat pendidikan mampu kesehatan, kenyamanan serta aspek politik.

\section{Jenis-Jenis Kemiskinan}

Kemiskinan dapat digolongkan menjadi beberapa jenis yaitu (Badrudin, 2012): 1) Kemiskinan relative, merupakan kondisi miskin karena pengaruh kebijakan pembangunan yang belum mampu menjangkau seluruh lapisan masyarakat sehingga menyebabkan ketimpangan distribusi pendapatan. Ukuran kemiskinan relatif sangat tergantung pada distribusi pendapatan/pengeluaran penduduk. Dengan definisi ini, orang miskin selalu hadir bersama; 2) Kemiskinan absolut, adalah jenis kemiskinan yang ditentukan berdasarkan ketidakmampuan untuk mencukupi kebutuhan pokok minimum seperti pangan, sandang, kesehatan, perumahan dan pendidikan yang diperlukan untuk mendapat hidup dan bekerja. Kebutuhan pokok minimum diterjemahkan sebagai ukuran finansial dalam bentuk uang. Nilai kebutuhan minimum/ kebutuhan dasar tersebut dikenal dengan istilah garis kemiskinan; 3 ) Kemiskinan structural, adalah kemiskinan yang ditengarai disebabkan oleh kondisi struktur atau tatanan yang tak menguntungkan karena tatan itu tidak hanya menyebabkan kemiskinan tetapi juga melanggengkan kemiskinan di dalam masyarakat. Di dalam kondisi struktur yang demikian, kemiskinan menggejala bukan oleh sebab-sebab alami melainkan disebabkan oleh tatanan sosial yang tidak adil; 4) Kemistkinan Kultural, adalah kemsikinan yang disebabkan oleh factorfaktor adat dan budaya suatu daerah tertentu membelenggu seseorang teteap melekat dengan indikator kemiskinan. Padahal indikator kemiskinan seyogyanya dapat dikurangi bahkan secara bertahap dapat dihilangkan dengan mengabaikan faktor - faktor adat dan budaya tertentu yang dapat menghalangi seseorang melakukan perubahan-perubahan ke arah tingkat kehidupan yang lebih baik.

\section{Indikator Kemiskinan}

Mengukur kemiskinan yang dipergunakan oleh BPS adalah konsep kemampuan dalam memenuhi kebutuhan dasar (basic needs approach). Dengan pendekatan ini kemiskinan dipandang sebagai ketidakmampuan dari sisi ekonomi untuk memenuhi kebutuhan dasar makanan dan non makanan yang diukur dari sisi pengeluaran (Badrudin, 2012). Batas kecukupan makanan dihitung dari besarnya rupiah yang dikeluarkan untuk 
makanan tertentu yang memenuhi kebutuhan minimum energy 2100 kilo kalori per hari perkapita. Sedangkan batas kecukupan non makanan seperti perumahan, sandang, kesehatan, pendidikan, transportasi, dan lain-lain (Maipita,2014).

Berdasarkan pendekatan kebutuhan dasar, ada 3 indikator kemiskinan yang dipergunakan adalah : 1) Head Count Index ( $\mathrm{HCl}-\mathrm{PO})$, yaitu presentase penduduk miskin yang berada di bawah garis kemiskinan (GK); 2) Indeks Kedalaman Kemiskinan (Poverthy Gap Index-P1) sebagai ukuran rata-rata kesenjangan pengeluaran masing-masing penduduk miskin terhadap garis kemiskinan. Semakin tinggi nilai indeks, semakin jauh rata-rata pengeluaran penduduk dari garis kemiskinan;

Indeks Keparahan Kemiskinan (Poverthy Severity Index- $P 2$ ) yang memberiksn gambaran mengenai penyebaran pengeluaran diantara penduduk miskin. Semakin tinggi nilai indeks, semakin tinggi ketimpangan pengeluaran diantara penduduk miskin.

\section{Mengukur Kemiskinan}

Mengukur kemiskinan dapat dilihat dari kebutuhan dasar (basic needd approach) seperti yang dipergunakan oleh Badan Pusat Statistik (BPS), model konsumsi pangan setara beras oleh Sayogyo dan model kesejahteraan keluarga yang dikeluarkan oleh Badan Koordinasi Keluarga Berencana (BKKBN). Jenis pengukuran tersebut diuraikan berikut.

1. Pendekatan Kebutuhan Dasar Oleh BPS.

Menurut BPS seseorang dikatakan miskin bila ia tidak mampu memenuhi kebutuhan dasarnya (basic needs), dengan kata lain, kemiskinan dipandang sebagai ketidakmampuan dari sisi ekonomi dalam memenuhi kebutuhan dasar, baik makanan maupun non makanan yang diukur dari sisi pengeluaran. Batas kecukupan kebutuhan makanan dihitung dari besarnya rupiah yang dikeluarkan untuk makanan tertentu yang memenuhi kebutuhan minimum energi 2100 kilo kalori per kapita per hari. Sedangkan batas kecukupan non makanan dihitung dari besarnya rupiah yang dikeluarkan untuk memenuhi kebutuhan non makanan seperti perumahan, sandang, kesehatan, pendidikan, transportasi dan lain-lain.

\section{Pendekatan Sayogyo}

Pada tahun 1970-an, Prof. Sayogyo menetapkan garis kemiskinan dengan menggunakan metode ekuivalensi daya beli beras berdasarkan dugaan pengukuran pendapatan. Suatu penduduk dikatakan miskin apabila pendapatannya kurang dari ekuivaleb harga beras sebanyak $480 \mathrm{~kg}$ per kapita per tahun bagi yang tinggal di daerah pedesaan, dan sebanyak 720 $\mathrm{kg}$ per kapita per tahun bagi yang tinggal di daerah perkotaan. Dalam konsep ini, garis kemiskinan di daerah pedesaan sebesar harga $480 \mathrm{~kg}$ beras, sedangkan di perkotaan sebesar harga $720 \mathrm{~kg}$ beras.

\section{Dimensi Kemiskinan Dalam Islam}

Kemiskinan dalam ekonomi Islam memiliki dimensi luas, tidak hanya terfokus dlam kemiskinan material yang bersifat absolut atau relative. Kemiskinan dalam ekonomi Islam disamping kemiskinan material juga mengenal kemiskinan aspek spiritual yang lebih mengarah pada dimensi moral, akhlaq mauapun jiwa. Manusia sebagai hamba Tuhan yang diberi kesempatan untuk hidup di dunia dan mengabdi kepada Tuhannya tidak bisa berjalan sesuai kehendak dirinya. Menusia membuntuhkan adanya sandaran untuk mencurahkan isi hatinya dari berbagai tantangan dan ujian hidup di dunia. Kemiskinan termasuk kaya adalah salah satu tanda dari sekian banyak tanda kekusaan Allah. Keduanya berjalan seiring dan saling membutuhkan satu dengan yang lainnya. Meskipun keduanya berbeda dan memiliki karakteristik yang berlainan, namun keduanya saling berdekatan dan saling berjauhan sekaligus. Keduanya fenomena ini saling menggerakkan kehidupan manusia di dunia, yaitu saling memberi dan saling menahan. Dari kedua prinsip itu muncul kehidupan yang subur dalak kekeringan dan kering dalam kesuburan, manis dalam kepahitan dan pahit dalam 
kemanisan (Al-Qubbani, 1999). Islam memerintahkan kepada manusia kaya untuk selalu memperhatikan manusia miskin. Manusia miskin akan pada hakekatnya manusia yang memiliki potensi dan kemampuan, namun dibalik potensi dan kemampuan yang dimiliki belum mampu memenuhi kebutuhan hidupnya.

\section{Hakikat Kemiskinan}

kemiskinan menurut Al-Qur'an terkait dengan tiga hal pokok yaitu ( Ibrahim, 2007 ):

1. Hubungan antara manusia dan harta benda. Hal ini menegaskan bahwa harta benda merupakan milik Allah yang didelegasikan kepada manusia. Oleh karenya kepemilikan manusia terhadap harta benda adalah pinjaman (milkiyah musytaqqah) dari kepemilikan Asli milik Allah SWT. Hubungan antara manusia dengan harta benda mengambil bentuk dua arah. Arah pertama, harta benda mendominasi manusia dan arah kedua manusia menguasai harta benda. Kedua arah ini ditentukan oleh aspek psikis manusia daam bentuk keyakinan kepada Tuhan dan pandangan terhadap dunia.

2. Pengertian fakir dan miskin. Al-Qur'an memakai beberapa kata dalam menggambarkan kemiskinan, tetapi fakir dan miskin serta berbagai bentuk keduanya paling banyak dipergunakan.AI-Qur'amengemukakan bahwa fuqara' adalah kelompok yang berhak memperoleh bagian zakat bersama kelompok-kelompok lain sebagai disebutkan dalam S.AtTaubah 60. Di samping berhak mendapatkan zakat, mereka juga berhak mendapat penyaluran lain seperti daging sembelihan. Sementara fakir adalah orang yang memerlukan bantuan dan dilakukan dengan pantas ( ma'ruf). Pada sisi lain Al-Qur'an mencirikan orang fakir adalah orang yang memiliki harta benda, tetapi karena sebab tertentu ia terpisah dari harta tersebut.

3. Kemiskinan yang dikaitkan dengan manusia dengan sunnah Allah. Jawaban masalah ini dapat dicari dengan cara mencurahkan pemahaman terhadap petunjuk AlQur'an , terutama ayat-ayat yang berkaitan dengan rejeki yang disebutkan sebanyak 123 kali. Kata tersebut digunakan untuk menyebut pemberian yang kontiniu baik bersifat internal (duniawi) maupun menyebut eksternal (ukhrawi); jatah (lal-nashib) ;makanan;hujan;kehormatan dan ilmu.

\section{Jenis - Jenis Kemiskinan}

Al-Qur'an sebagai sumber hukum mengelompokkankemiskinandalam

beberapa jenis yaitu (Arraiyah, 2007) :

1. Kemiskinan materi yaitu keadaan manusia yang berada pada taraf memebutuhkan, tidak mampu memenuhi kebutuhan sehingga perlu dibantu oleh orang lain. Kebutuhan yang dimaksud adalah kebutuhan pangan yang merupakan satu-satunya kebutuhan rohani yang bersifat pokok yang merupakan kodrat hidup manusia dan njika diabaikan manusia akan mengalami kematian. Allah berfirman dalam surah Al-Anbiya ayat 8 :

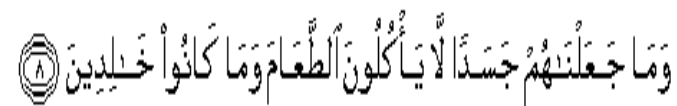

Artinya : Dan tidaklah Kami jadikan mereka tubuh-tubuh yang tiada memakan makanan, dan tidak (pula) mereka itu orang-orang yang kekal.

2. Kemiskinan jiwa/rohani adalah keadaan jiwa yang buruk dan tercermin dalam bentuk sikap negative, seperti rendah diri atau kehinaan, kehilangan gairah atau pesimis, dan perasaan tidak puas dengan apa yang diperolehnya. Kemiskinan ini erat kaitannya dengan apa yang dinamakan kemiskinan moral.

3. Kemiskinan daam arti khusus yaitu kebutuhan manusia kepada penciptanya. Pandangan ini terikat dengan dimensi spiritual yang ada pada diri manusia. Akan tetapi, tidak semua orang menyadari atau menunjukkan kepedulian terhadap hal ini.

Isjrin Noerdin (1986) mengatakan bahwa umat manusia hidup pada tiga dunia yaitu (1) dunia keadaannya; ia berada 
dilingkungan fisik,materinya, (2) dunia sosialnya ; (3) dunia spiritual ; tempat ia memenuhi kebutuhan spiritualnya "food of the main". Lebih lanjut ia berpendapat bahwa ada tiga jenis kemiskinan yaitu kemiskinan materi, kemiskinan social dan kemiskinan spiritual. Ketiganya mungkin tidak emmepunyai hubungan antara satu dengan yang lainnya. Gangguan terhadap keseimbangan antara tiga alam manusia yaitu materi, social dan spiritual adalah sebab utama kemiskinan (dalam arti luas). Mengacu pada tiga jenis kemiskinan ini, Al-Qur'an tidak hanya terfokus pada kemiskinan material namun harus diperhatikan pula kemiskinan non materi (nirmateri) yang jauh lebih rumit dan membawa dampak yang sangat ;uar biasa terhadap kehidupan manusia selanjutnya. Kondisi kemiskinan nirmateri ini sebenarnya telah dicemaskan oleh Rasulullah SAW melalui sabda beliau yang artinya : "kemiskinan material yang kamu derita tidaklah begitu mencemaskan. Yang palinbg saya khawatirkan adalah jika kelak sudah terbuka dihadapan kamu sekalian kemewahan hidup duniawi seperti yang dinikmati oleh umat-umat sebelum kamu, lalu saling berebut sebagaiman umatumat terdahulu saling memperebutkan. Maka kemewahan itulah yang menghancurkan binasakan kamu, seperti umat-umat terdahulu telah dihancur binasakan" (HR. Bukhari dan Muslim).

Hadist ini mengisyaratkan bahwa kemiskinan material merupakan suatu kondisi yang dialami oleh manusia dan harus dicarikan solusinya. Pemecahan dan penanganan kemiskinan material akan berhasil manakala penduduk miskin telah terpenuhi kebutuhan hidup sesuai dengan indikator yang telah ditentukan (Maqashid Syariah). Kondisi ini tidaklah mengkhawatirkan bagi Rasulullah SAW karena dalam jangka waktu tertentu manusia dapat memenuhi kebutuhan minimaknya. Hal ini dapat dicapai apabila manusia yang tergolong miskin melakukan pekerjaan atau mendapat bantuan dari pohak lain. Tetapi yang mencemaskan beliau adalah pola hidup manusia yang berlomba-lomba untuk mencari kemewahan kehidupan duniawi yang melalaikan norma-norma dan cara- cara yang serba boleh. Kondisi yang tengan berlangsung dengan maraknya di tengah-tengah kehidupan manusia.

\section{METODE PENELITIAN}

\section{Jenis Penelitian}

Jenis penelitian yang dipergunakan dalam penelitian ini adalah penelitian deskriptif yang mendeskripsikan dan memberikan gambaran tentang kondisi kemiskinan di Nusa Tenggara Barat dari tahun 2009 2016 dilihat dari berbagai dimensi kemiskinan. Hal ini dimaksudkan memberikan informasi dan gambaran yang jelas berkenaan jumlah penduduk yang masih tergolong miskin, persentase penduduk miskin, garis kemiskinan, kemiskinan di daerah perkotaan dan pedesaan, indeks kedalaman dan keparahan kemiskinan.

Berdasarkan fakta tersebut, diungkapkan pula langkah - langkah kebijakan yang telah dan akan ditempuh oleh pemerintah Provinsi Nusa Tenggara Barat berkenaan dengan penanganan penduduk miskin. Penanganan tersebut sejalan dengan kebijakan pengentasan kemiskinan yang dilakukan oleh Pemerintah pusat. Di samping itu, dijelaskan juga upaya dan cara pemecahan kemiskinan dalam pandangan ekonomi Islam.yang merujuk pada Al-Qur'an, Al-Hadist maupun ijtihad dari para ulama-ulama kontemporer.

\section{Lokasi Penelitian}

Penelitian dilakukan di Provinsi Nusa Tenggara dan juga kondisi diseluruh kabupaten/kota yang berada di Nusa Tenggara Barat, dengan memperhatikan ketersediaan data sesuai yang dibutuhkan dalam analisis ini. Periode penilitian dilakukan selama 8 tahun dari tahun 2009 -2016. Hal ini didasarkan pada pertimbangan kemukhtahiran data serta informasi yang mengandung aspek-aspek yang dikaji dalam penelitian ini. $\mathrm{Di}$ samping itu, sebagai bahan kajian untuk memformulasikan permasalahan yang berkaitan dengan kemiskinan penduduk.

\section{Jenis dan Sumber Dana}

Penelitian ini sepenuhnya menggunakan data sekunder yang bersumber dan berbagai instansi seperti BPS NTB, Bappeda NTB, dan berbagai literature dan 
informasi yang berkaitan dengan analisis penelitian ini.

Adapun jenis data yang dibutuhkan adalah:

a. Data jumlah penduduk di NTB 20092016

b. Jumlah penduduk yang tergolong miskin di NTB tahun 2009-2016 baik di daerah Perkotaan maupun pedesaan.

c. Data garis kemiskinan di NTB tahun 2009-2016.

d. Data Indeks kedalaman dan keparahan kemiskinan

e. Data penunjang berkaitan dengan kemiskinan.

\section{Analisis Data}

Untuk mencapai tujuan analisis ini, analisis dilakukan secara kualitatif dan kuantatif.

a. Analsis kualitatif diperlukan untuk menjelaskan kondisi riel yang terjadi didasarkan pada hasil pengamatan danm pembahasan oleh peneliti berdasarkan data, kemudian dikaitkan dengan penelitian yang sama pada daerah lain maupun berbagai literature

b. Analisis kuantitatif dipergunakan untuk melihat adanya flaktuasi dari data kemiskinan dengan menghitung pertumbuhan masing-masing indicator dengan menggunakn formulasi (Widodo, 1990) :

a. Cara Tahunan :

$$
\Delta=X i_{n}-X i_{n-1} / X i_{n-1} \times 100 \%
$$

b. Cara Rata-Rata setiap tahun

$G m=\sqrt[n-1]{X 1 \times X 2 \times X 3 \ldots \times X n}$

atau $r=\sqrt[n-1]{\frac{X n}{X o}}-1$

Dimana :

$\mathrm{Xn}=$ Tahun akhir analisis

$X_{n-1}=$ Tahun sebelum analisis

$\mathrm{n}=$ jumlah tahun analisis (selang waktu)

Penelitian ini ditunjuk untuk mendeskripsikan penduduk yang tergolong miskin dalam beberapa aspek, namun juga dideskripsikan beberapa aspek yang berkaitan dengan kemisikinan seperti :

a. Perkembangan garis kemiskinan .

b. Penyebab kemiskinan menurut ekonomi konvensional dan ekonomi Islam. c. Strategi ekonomi Islam dalam memecahkan permasalahan kemiskinan.

\section{HASIL DAN PEMBAHASAN}

\section{Kemiskinan di Nusa Tenggara Barat}

\section{Jumlah Penduduk Miskin}

Jumlah penduduk miskin di Provinsi Nusa Tenggara Barat (NTB) mengalami perkembangan yang terkadang cukup menggembirakan dan juga cukup memprihatinkan. Hal ini sejalan dengan terjadinya dinamika jumlah penduduk miskin baik secara nasional maupun regional. Kebijakan pengurangan penduduk miskin merupakan kebijakan strategis yang dilakukan oleh pemerintah pusat maupun NTB, karena kemiskinan merupakan salah satu penyakit sosial yang mengancam kestabilan keamanan nasional. Pemerintah Provinsi NTB, telah menetapkan target penurunan penduduk miskin pada setiap priode pemerintahan, yang diimplementasikan dalam kebijakan penanganan kemiskinan setiap tahun.

Ihktiar menurunkan penduduk miskin yang disusun dan diprogramkan tidak parsial, melainkan harus merujuk pada strategi pengentasan penduduk baik secaral global maupun nasional. Strategi tersebut diimplementasikan melalui arah kebijakan berupa 1) peningkatan kualitas pelayanan terhadap hak-hak dasar manusia; 2) peningkatan aksesibilitas masyarakat terhadap sumber modal sarana prasarana ekonomi; 3) peningkatan pendapatan masyarakat. Kebijakan umum yang ditempuh adalah 1) mempercepat pemenuhan pelayanan kebutuhan dasar masyarakat miskin; 2) mendorong tumbuh dan berkembangnya lembaga keuangan mikro dan sarana pendukung perekonomian sampai tingkat pedesaan; 3) mendorong tumbuh dan berkembangnya pusat-pusat agrinisnis dan agro industri; 4) mendorong timbul dan berkembangnya wilayah strategis dan cepat tumbuh (RPJMD 2009 -2013). Kebijakan umum yang dilakukan secara bertahap tersebut telah menurunkan jumlah penduduk miskin memberikan hasil yang cukup menggembirakan meski 
belum mencapai target yang telah ditentukan.

Tabel 1. Jumlah dan Pertumbuhan Penduduk Miskin di Nusa Tenggara Barat Tahun 2009 - 2016.

\begin{tabular}{|c|c|c|}
\hline Tahun & Jumlah (Jiwa) & Pertumbuhan (\%) \\
\hline 2009 & 1.050 .948 & 0 \\
\hline 2010 & 1.009 .352 & $-3,96$ \\
\hline 2011 & 900.573 & $-10,78$ \\
\hline 2012 & 840.108 & $-6,71$ \\
\hline 2013 & 815.501 & $-2,93$ \\
\hline 2014 & 816.621 & 0,14 \\
\hline 2015 & 802.290 & $-1,75$ \\
\hline 2016 & 786.580 & $-1,96$ \\
\hline
\end{tabular}

Sumber : BPS NTB, diolah. (Kondisi Bulan September setiap tahun)

Menurunkan jumlah penduduk miskin terus menjadi program prioritas pemerintah NTB. Dalam Rencana Pembangunan Jangka Menengah Daerah (RPJMD) tahun 2013 - 2018 kebijakan kebijakan yang berkaitan dengan kemiskinan dituangkan dalam Misi kelima yaitu Meningkatkan kesejahteraan masyarakat, mempercepat penurunan kemiskinan dan mengembangkan keunggulan daerah. Tujuannya dari misi kelima tersebut adalah 1) Meningkatkan efektivitas pemanfaatan sumberdaya alam; 2) Meningkatkan produktivitas kualitas dan varietas komoditi; 3) Meningkatkan efektivitas pelayanan investasi; 4) Meningkatkan sumber pendanaan daerah; 5) Meningkatkan konentivitas perekonomian antar kawasan, antar kota, antar wilayah (RPJMD NTB, 2013 - 2018). Penurunan jumlah penduduk miskin di NTB dapat dilihat dari pertumbuhan. Dengan tingkat pertumbuhan negatif 10,78 \% menempatkan daerah NTB sebagai salah satu daerah yang mampu menurunkan jumlah penduduk miskin yang tergolong baik. Rata - rata pertumbuhan penduduk miskin di NTB dari tahun 2009 - 2016 mencapai $-3,19 \%$.

Permasalahan mendasar yang berkenaan dengan penduduk miskin adalah penyebaran yang tidak merata antar wilayah kabupaten/kota yang berada di Pulau Lombok dan Pulau Sumbawa. Kondisi penduduk miskin di Pulau Lombok rata-rata sebesar $72,81 \%$, sementara di pulau Sumbawa hanya rata-rata 27,19 dari total penduduk miskin di Nusa
Tenggara Barat tahun 2009 - 2016. Hal ini mengindikasikan bahwa pulau Lombok yang luasnya hanya $22,78 \%$ dari luas NTB harus menampung sebanyak 70,87 $\%$ jumlah penduduk dan tergolong miskin. Pulau Sumbawa yang luas wilayahnya mencapai $72,22 \%$ dari luas provinsi NTB hanya menampung sekitar 29,13\% penduduk, meskipun ada yang tergolong miskin tetapi jumlahnya lebih sedikit dibanding pulau Lombok.

Terpusatnya penduduk yang mendiami pulau Lombok telah menjadi pemikiran oleh pemerintah untuk melakukan strategi penanganan kemiskinan yang disesuaikan dengan kondisi budaya pada tiap-tiap daerah. Di samping itu, program pemerataan penduduk terus dilakukan dengan melalui transmigrasi secara nasional maupun lokal. rogram lain adalah berkaitan dengan penanganan pembatasan untuk memprogramkan jarak kelahiran. Jumlah penduduk miskin pada setiap kabupaten/Kota menunjukkan kecenderungan menurun dari tahun ke tahunnya. Kendati demikian, jumlah penduduk miskin ini cenderung berubah bila terjadi berbagai peristiwa yang dapat menjadi pemicu munculnya kemiskinan, tidak hanya terjadi pada penduduk yang memang tergolong miskin, juga bisa terjadi pada penduduk yang sementara ini besarnya pendapatan dan pengeluaran masih berada di sekitar garis kemiskinan. Gambaran jumlah penduduk miskin berdasarkan kabupaten/kota terlihat dalam lampiran 1.

Keberhasilan pemerintah provinsi NTB menurunkan jumlah penduduk miskin 
tidak terlepas dari adanya kebijakan kebijakan strategis yang berkenaan dengan peningkatan harkat dan martabat penduduk miskin. Kebijakan dan program -program strategis ada yang berhubungan langsung dengan penduduk miskin terutama berkaitan dengan obyek obyek vital kebutuhan hidup manusia. Peningkatan kualitas pendidikan, kesehatan dan pembukaan kesempatan kerja baru merupakan beberapa program yang secara langsung berkaitan dengan penduduk miskin. Membuka lapangan kerja baru misalnya, adalah salah satu jalan yang ditempuh agar masyarakat memiliki sumber pendapatan yang pasti yang dimanfaatkan untuk memenuhi kebutuhan hidup terutama kebutuhan dasar atau kebutuhan pokok. Selain itu pembangunan sarana dan prasarana seperti pasar dan fasilitas - fasilitas pendukungnya juga merupakan salah satu cara untuk menurunkan penduduk miskin. Dengan kebijakan yang berpihak kepada masyarakat miskin (pro poor) setidaknya akan mempermudah pemerintah provinsi NTB mencapai target penurunan kemiskinan setiap tahun.

Pintu yang telah dibuka oleh pemerintah harus dimanfaatkan secara baik oleh masyarakat terutama yang terglong miskin agar mampu merubah kualitas hidupnya. Namun demikian, setiap kebijakan dan program yang telah digelontorkan oleh pemerintah terkendala oleh faktor dari dalam diri penduduk miskin. Kendala lain yang dihadapi adalah kualitas penduduk miskin untuk masuk ke lapangan kerja yang bersifat formal. Denga kualitas sumber daya yang sangat rendah dilihat dari berbagai dimensi, penduduk miskin hanya bisa bekerja pada sektor - sektor informal yang tidak mebutuhkan syarat syarat tertentu, tetapi tidak memberikan jaminan pendapatan atau upah yang memadai. Besarnya pendapatan yang diterima tidak mampu untuk ditukar dengan barang - barang yang memang menjadi kebutuhan dasarnya. Dengan kondisi yang demikian, penduduk miskin tetap berada pada kemiskinan dan rentan menimbulkan permasalahan lainnya yang sering bersahabat dengan penduduk miskin.

\section{Persentase Penduduk Miskin}

Secara persentase jumlah penduduk miskin di Provinsi NTB mengalami penurunan dari tahun ke tahun, meskipun penurunan tersebut belum mampu untuk memenuhi target yang telah ditetapkan. Pada tahun 2008 persentase penduduk miskin di Priovinsi NTB sebesar 24,99\% dan tahun 2013 ditargetkan akan mencapai $14 \%$. Ikhtiar dan kerja keras pemerintah untuk menurunkan jumlah maupun persentase penduduk miskin tidaklah mudah dan mendapat berbagaikendaladalam pelaksanannya baik bersifat internal maupun eksternal. Banyak faktor yang mempengaruhi sehingga target yang telah ditetapkan belum tercapai. Kendati demikian, kemampuan pemerintah Provinsi NTB menurunkan jumlah penduduk miskin merupakan sebuah prestasi yang telah mendapat apreasi oleh pemerintah pusat karena tergolong sebagai provinsi yang paling progresif di dalam menurunkan angka kemiskinan secara nasional.

Persentase penduduk miskin yang terdapat di Provinsi NTB masih lebih tinggi dibandingkan dengan persentase penduduk miskin secara nasional selama tahun 2009 - 2016. Namun dilihat percepatannya tampaknya penurunan persentase penduduk miskin di Nusa Tenggara Barat lebih cepat meski pada tahun - tahun tertentu mengalami perlambatan. Hal ini mencerminkan kinerja pemerintah NTB menurunkan penduduk miskin telah memberikan hasil meskipun belum sepenuhnya memuaskan. 
Gambar 1. Persentase Penduduk Miskin di NTB dan Nasional 2009 - 2016.

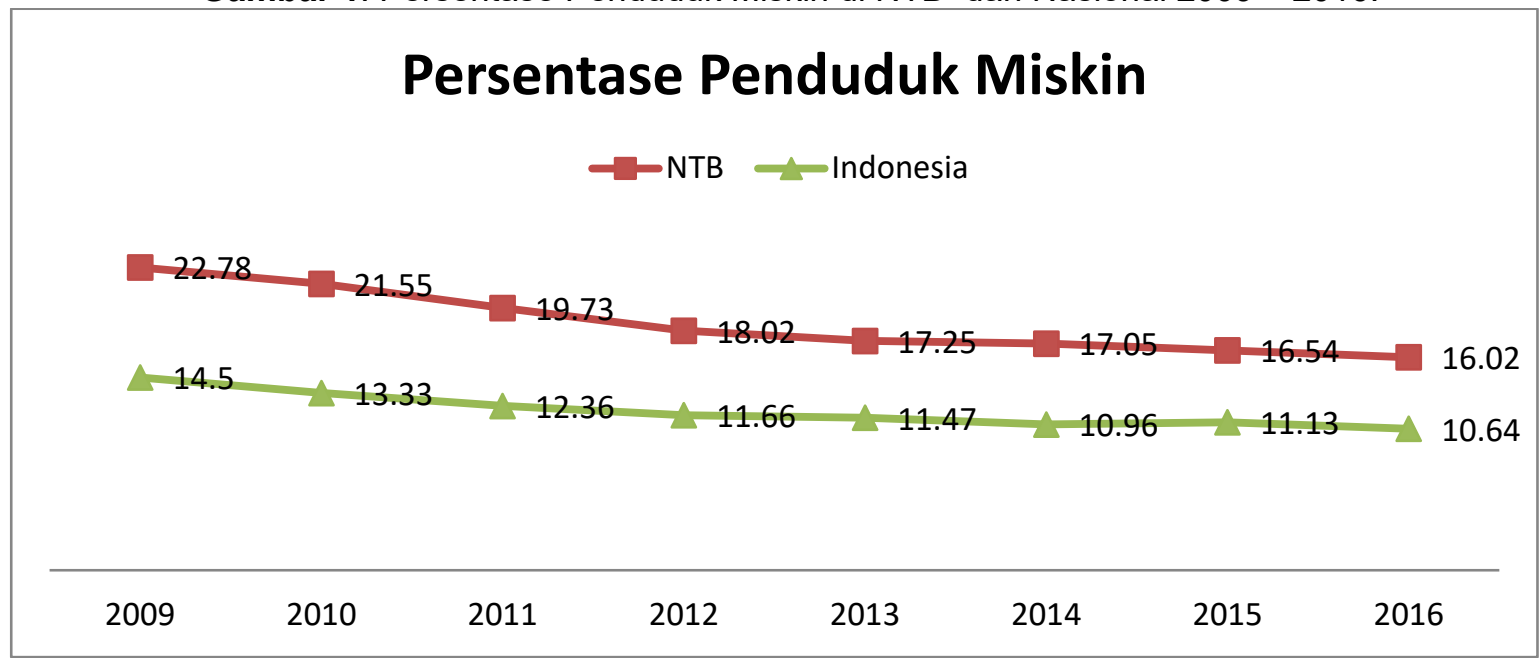

Penduduk miskin di NTB secara persentase mengalami penurunan. Pergerakan jumlah penduduk miskin awalnya berada di atas $1 \%$, yaitu pada tahun 2009 - 2012, namun sejak tahun 2013 hingga tahun 2016 pergerakannya melambat dan berada sekitar 0,20-0,52 $\%$. Perlambatan penurunan persentase penduduk miskin pada empat tahun terakhir, disebabkan oleh berbagai faktor, tidak saja faktor yang bersifat ekonomi, juga disebabkan oleh faktor - faktor yang bersifat non ekonomi. Penurunan persentase penduduk miskin pada tahun 2013 - 2016 memberikan makna bahwa penduduk miskin di provinsi NTB selama kurun waktu tersebut terjadi pertambahan, seiring dengan terjadinya perubahan aktivitas masyarakat, baik dalam meraih kesempatan kerja atau terjadinya perubahan pendapatan yang diterima. Terjadinya fluktuasi pendapatan yang diterima berpengaruh pada kemampuan untuk memenuhi kebutuhan hidupnya terutama pemenuhan kebutuhan pokok. Secara grafik besarnya perubahan persentase penduduk miskin di Provinsi Nusa Tenggara Barat terlihat dalam gambar berikut.

Gambar 2. Perubahan Persentase Penduduk Miskin di

Nusa Tenggara Barat dan Nasional Tahun 2009 - 2016.

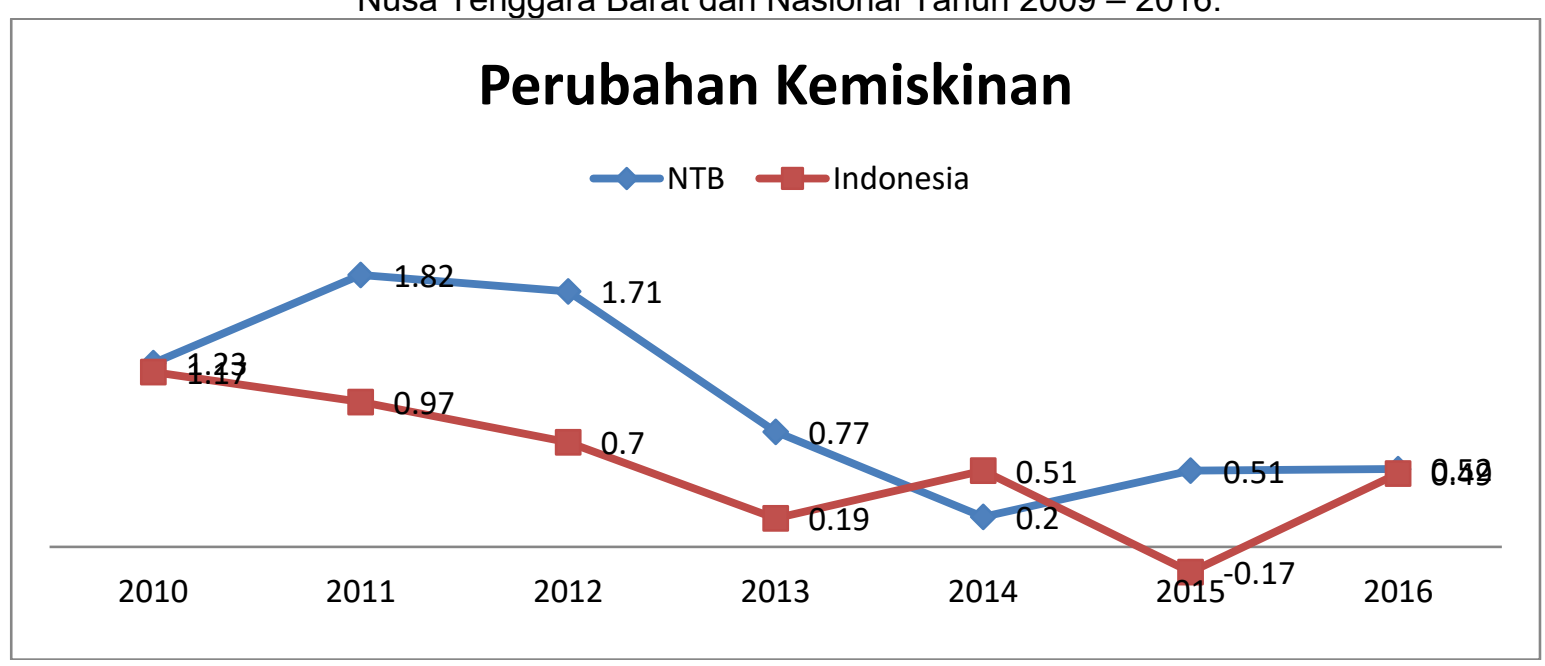

Perubahan persentase penduduk miskin di Provinsi Nusa Tenggara barat selama tahun 2009 - 2013 jauh lebih tinggi dibandingkan dengan kondisi secara nasional. Keadaan inilah merupakan prestasi terbaik yang diraih oleh 
pemerintah provinsi Nusa Tenggara Barat dalam ikhtiar menurunkan penduduk dari jeratan kemiskinan. Namun, tahun 2014 kondisinya jauh lebih lambat dibanding dengan nasional, meskipun pada tahun 2015 kembali lebih cepat bahkan pada tahun 2016 kondisinya hampir sama. Kondisi di atas menunjukkan bahwa performa persentase kemiskinan di provinsi Nusa Tenggara Barat khuhusnya tiga tahun terakhir memberikan hasil yang cukup menggembirakan karena perubahannya masih atau relatif sama dengan perubahan secara nasional.

\section{Penduduk Miskin Berdasarkan Daerah}

Penduduk miskin baik secara nasional maupun yang berada di provinsi Nusa Tenggara Barat dapat diklasifikasikan berdasarkan daerah perkotaan dan pedesaan. Hal ini dimaksudkan agar dapat diketahui secara jelas sebaran penduduk miskin, agar dapat dibuat langkah-langkah kebijakan strategis berkaitan dengan penanganan kemiskinan di wilayah perkotaan dan pedesaan. Sebaran penduduk miskin di perkotaan dan pedesaan terlihat dalam tabel berikut.

Tabel 2. Jumlah Penduduk Miskin Di Provinsi Nusa Tenggara Barat

Berdasarkan Daerah Perkotaan dan Pedesaan Tahun 2009 - 2016.

\begin{tabular}{|l|c|c|c|c|c|c|}
\hline \multirow{2}{*}{ Tahun } & \multicolumn{7}{|c|}{ Jumlah Penduduk Miskin } \\
\cline { 2 - 7 } & Kota (jiwa) & $\%$ & Desa (Jiwa) & $\%$ & Kota + Desa (Jiwa) & $\%$ \\
\hline 2009 & 557.539 & 28,84 & 493.409 & 18,40 & 1.050 .948 & 22,78 \\
\hline 2010 & 552.617 & 28,16 & 456.735 & 16,78 & 1.009 .352 & 21,55 \\
\hline 2011 & 445.230 & 23,42 & 450.960 & 16,99 & 896.190 & 19,67 \\
\hline 2012 & 415.380 & 21,56 & 412.940 & 15,41 & 828.330 & 18,02 \\
\hline 2013 & 364.080 & 18,69 & 438.370 & 16,22 & 802.450 & 17,25 \\
\hline 2014 & 385,310 & 19,17 & 431,310 & 15,52 & 816,620 & 17,05 \\
\hline 2015 & 377.280 & 18,40 & 425.010 & 15,18 & 802.290 & 16,54 \\
\hline 2016 & 378.830 & 17,55 & 407.750 & 14,82 & 786.580 & 16,02 \\
\hline
\end{tabular}

Sumber : Kantor BPS NTB, Bappeda NTB, 2010 - 2017

Penduduk miskin di daerah perkotaan dan pedesaan mengalami fluktuasi baik dari jumlah abslout maupun secara persentase. Penduduk miskin yang berada di daerah pedesaan meskipun setiap tahun mengalami penurunan, tetapi masih lebih banyak dibanding dengan daerah perkotaan. Kondisi internal dari setiap penduduk penyandang kemiskinan merupakan faktor utama yang menyebabkan timbulnya kemiskinan di kota. Persaingan memasuki lapangan kerja pada sektor formal yang semakin ketat, akses untuk berhubungan dengan lembaga-lembaga ekonomi yang semakin terbatas dan sulit serta prilaku kehidupan yang mengarah pada individualistis merupakan faktor ekternal yang mempengaruhinya. Kemiskinan penduduk di daerah perkotaan juga dapat ditilik dari penduduk yang belum dan tidak memiliki pekerjaan yang berdampak tidak memiliki sumber pendapatan sama sekali atau tergolong penganggur. Golongan ini terdapat pada berbagai jenjang pendidikan, mulai pada jenjang sekolah dasar hingga pada jenjang pendidikan tinggi. Fakta ini akan semakin mempersulit dalam pengentasan kemiskinan, karena dengan latar pendidikan yang dimiliki (khususnya pendidikan tinggi) belum menjamin untuk mudah masuk pasar kerja.

Kemiskinan penduduk di daerah pedesaan, mengalami dinamika yang berbeda dengan daerah perkotaan. Meskipun jumlah lebih besar dibanding daerah perkotaan, namun penurunan jumlahnya lebih banyak.. Penduduk miskin di pedesaan masih menjadi permasalahan yang mendapat perhatian untuk dipecahkan, mengingat cikal bakal tumbunya sumber daya manusia yang berkualitas diharapkan akan datang dan tumbuh dari daerah pedesaan. Penduduk pedesaan yang mengandalkan kehidupan pada sektor pertanian, perikanan, kehutanan dan berkaitan langsung dengan kehidupan alam, dihadapkan oleh suatu kondisi yang penuh ketidakpastian. Aktivitas kehidupan yang sebahagian besarnya bergantung pada kondisi alam, berdampak pada banyak sedikitnya hasil 
yang diperoleh dan berimbas pula pada besar kecilnya pendapatan.

Sentuhan kebijakan dan model pengembangan penduduk miskin yang tepat akan secara cepat berdampak untuk menurunkan penduduk dari kungkungan kemiskinan di daerah pedesaan. Potensi daerah pedesaan yang masih berpeluang untuk dikembangkan akan membuka peluang dan kesempatan bagi penduduk miskin di daerah pedesaan untuk mengembangkan dan meningkatkan kualitas kehidupannya. $\mathrm{Hal}$ ini dikarenakan bila terjadi pertumbuhan sektor pertanian karena bersifat elastis terhadap pengentasan kemiskinan. Studi empiris yang dilalukan oleh Bank Indonesia (2008) menunjukkan bahwa setiap peningkatan pertumbuhan sektor pertanian sebesar 1 persen akan menurunkan tingkat kemiskinan nasional sebesar 2,76 persen dan menurunkan kemiskinan di sektor pertanian sebesar 7,34 persen. Bandingkan dengan sektor industri yang hanya menurunkan 0,11 persen kemiskinan nasional dan 1,59 persen sektor industri (Stamboel, 2012).

Pengembangan daerah pedesaan tidak hanya terfokus pada komoditi yang menjadi produk utama seperti komodiri pangan, namun harus dilakukan diversifikasi dengan melakukan penganekaragaman hayati yang mendukung berkembanganya sektor sektor lain. Daerah Nusa Tenggara Barat yang memiliki keindahan alam yang mempesona yang menjadi daya tarik wisatawan dapat mengembangkan komoditi pertanian yang menunjang kehadiran para wisatawan di daerah tersebut. Wisata mensyaratkan adanya estetika dan keindahan, sehingga dapat dikembangkan produk - pertanian yang mendukung syarat tersebut. Pengembangan daerah agrowisata yang telah dilakukan dapat ditingkatkan dan diperluas, sehingga ketergantungan petani untuk menghasilkan pangan sebagai produk utama dapat didifersifikasi yang berdampak pada bervariasinya sumber pendapatan yang diperoleh.

Pengembangan sektor industri yang tumbuh dari pedesaan yang memanfaatkan produk - produk pertanian sebagai bahan baku terus dilakukan dengan melakukan penguatan penguatan pada sektor tersebut. Konsep pembangunan industri pedesaan yang berbasis pertanian seperti istilah One Village One Product (OVOP) yaitu setiap desa hanya menghasilkan satu produk menjadikan daerah pedesaan akan berkembang cepat, terlebih pada setiap desa tersebut melibatkan penduduk penduduk yang berkutat kehidupan pada sektor pertanian tradisional menuju kehidupan industri yang berbasis pertanian modern. Menurut Sumodiningrat dkk, (2015), OVOP dapat terwujud karena dibangun oleh dasar- dasar yang kokoh yaitu : 1) Kebersamaan satu desa; 2) Revitalisasi desa (revitalization of People); 3) Revitalisasi desa (revitalization of villages); 4) Revitalisasi perdagangan (revitalization of comerce); 5) Pertukaran (exchange).

Dasar - dasar yang kokoh ini akan menjadi faktor pendorong dan pendukung utama dalam keberlangsungan usaha bagi sekelompok penduduk. Adanya rasa kebersamaan yang disertai saling memahami karakter masing - masing dipastikan akan mampu meningkatkan kualitas, kuantitas dan sanggup untuk menjaga dan menjalankan segala keputusan yang telah ditetapkan secara bersama. Oleh karenanya diperlukan kebesaran jiwa dari penduduk desa yang telah tergabung dalam suatu komunitas untuk secara bahu membahu dan bersama memajukan produk yang ada.

Spesialisasi produk pada setiap desa akan dapat dikembangkan dengan tetap memberikan perhatian pada kesinambungan usaha, baik dalam kualitas produk maupun pada aspek pemasarannya. Terjaminnya pasar akan menjadi faktor pendorong bagi pelaku usaha di desa tersebut untuk terus melakukan produksi agar mampu menciptakan sumber pendapatan yang permanen bagi penduduk setempat. Peningkatan kualitas sumber daya manuasia pelaku usaha di pedesaan merupakan salah satu skala prioritas yang dilakukan. Kegiatan inu tertuju terutama dalam pengetahuan terhadap pemanfaatan teknologi sehingga terjadi perubahan dalam melakukan aktivitas produksi dari yang bersifat tradisional 
menjadi modern dengan memanfaatkan kemajuan teknologi.

\section{Garis Kemiskinan}

Garis kemiskinan merupakan suatu patokan yang dijadikan dasar penetapan suatu rumah tangga dikatagorikan miskin atau tidak miskin. Penentuan garis kemiskinan di beberapa negara berbedabeda ada yang menggunakan pendapatan per kapita di bawah $50 \%$ dari angka ratarata dan ada juga yang menggunakan pengeluaran per kapita per hari sebesar \$ 1(Maipita, 2014). Garis kemiskinan di Indonesia masih mengacu pada standar yang ditentukan oleh BPS yang ditentukan berdasarkan pengeluaran jenis makanan dan non-makanan. Untuk pengeluaran jenis makanan yang dihitung disetarakan dengan banyaknya kalori minimal sebanyak 2100 kalori per kapita per hari, yang diwakili oleh sebanyak 52 jenis komoditi. Sedangkan pengeluaran non makanan adalah kebutuhan minimum untuk perumahan, sandang, pendidikan dan kesehatan. Paket komoditi non makanan diwakili oleh 51 jenis komoditi di perkotaan dan 47 jenis komoditi di pedesaan.

Garis kemiskinan di provinsi NTB selama tahun 2009 - 2016 selalu mengalami perubahan. Garis kemiskinan di daerah perkotaan lebih tinggi dibanding daerah pedesaaan. Hal ini mengindikasikan bahwa di daerah perkotaan lebih peka terhadap perubahan harga barang maupun jasa di baniding dengan daerah pedesaan. Peningkatan jumlah garis kemiskinan untuk komponen makanan lebih besar dibanding dengan peningkatan komponen non makanan baik yang terjadi di daerah perkotaan.

Tabel 3. Garis Kemiskinan Daerah Perkotaan dan Pedesaan Bedasarkan Jenis Makanan dan Non-Makanan di Provinsi NTB Tahun 2009 - 2016

\begin{tabular}{|c|c|c|c|c|c|c|c|c|c|}
\hline \multirow{2}{*}{ Tahun } & \multicolumn{6}{|c|}{ Garis Kemiskinan (Rp) } \\
\cline { 2 - 10 } & \multicolumn{3}{|c|}{ Kota } & \multicolumn{3}{c|}{ Desa } & \multicolumn{3}{c|}{ Kota + Desa } \\
\cline { 2 - 10 } & 1 & 2 & 3 & 1 & 2 & 3 & 1 & 2 & 3 \\
\hline 2009 & 155.698 & 57.752 & 213.450 & 130.973 & 33.553 & 164.526 & 141.433 & 43.692 & 185.025 \\
\hline 2010 & 162.477 & 61.307 & 223.778 & 139.896 & 36.387 & 176.283 & 149.358 & 46.827 & 196.185 \\
\hline 2011 & 193.383 & 71.752 & 265.135 & 167.037 & 43.009 & 210.046 & 178.031 & 55.002 & 233.033 \\
\hline 2012 & 202.822 & 72.057 & 274.879 & 182.147 & 47.907 & 230.054 & 190.774 & 57.984 & 248.758 \\
\hline 2013 & 218.873 & 81.013 & 299.886 & 209.138 & 53.969 & 263.107 & 213.216 & 65.298 & 278.514 \\
\hline 2014 & 231.917 & 85.553 & 315.470 & 228.485 & 69.423 & 297.907 & 228.485 & 69.423 & 297.907 \\
\hline 2015 & 244.162 & 91.123 & 328.125 & 238.879 & 74.588 & 313.466 & 241.112 & 81.577 & 322.689 \\
\hline 2016 & 252.343 & 94.237 & 346.581 & 249.501 & 79.274 & 328.775 & 250.737 & 85.836 & 336.573 \\
\hline
\end{tabular}

Sumber : BPS NTB $2009-2016$.

Keterangan : 1) Makanan; 2) Non Makanan; 3) Total.

Besarnya garis kemiskinan sebagaimana yang terlihat dalam tabel di atas, menunjukkan adanya variasi peningkatan garis kemiskinan antara daerah perkotaan dan daerah pedesaan. Melihat pergerakan perubahan garis kemiskinan yang terus meningkatan dari tahun ke tahun dapat dikatakan bahwa dengan semakin meningkatnya garis kemiskinan membawa dampak terhadap peningkatan jumlah penduduk miskin di Provinsi Nusa Tenggara Barat. Garis kemiskinan antara daerah perkotaan dan pedesaan pada tahun 2016 pada komponen makanan tidak terdapat perbedaan yang signifikan hanya selisih sebesar $\mathrm{Rp} 2.842,-.$. Kondisi ini lebih rendah dibanding dengan selisih tahun sebelumnya sebesar Rp 5.283,- maka terjadi penurunan sebesar Rp 2.441,-. Sementara pada komponen 
bukan makanan selisihnya sebesar Rp 14.963 pada tahun 2016, lebih kecil dibanding selisih pada tahun 2015 tahun sebelumnya yang mencapai sebesar Rp 16.535,-. Garis kemiskinan untuk daerah Perkotaan dan Pedesaan mengalami peningkatan yang berfluktuatif dari tahun ke tahun. Peningkatan ini juga sejalan dengan terjadinya peningkatan yang terjadi pada daerah perkotaan dan daerah pedesaaan. Penigkatan garis kemiskinan untuk komponen makanan lebih besar dibanding peningkatan garis kemiskinan untuk komponen bukan makanan.

Gambar 3. Kenaikan Garis Kemiskinan di Provinsi NTB tahun 2010 - 2016 (\%).

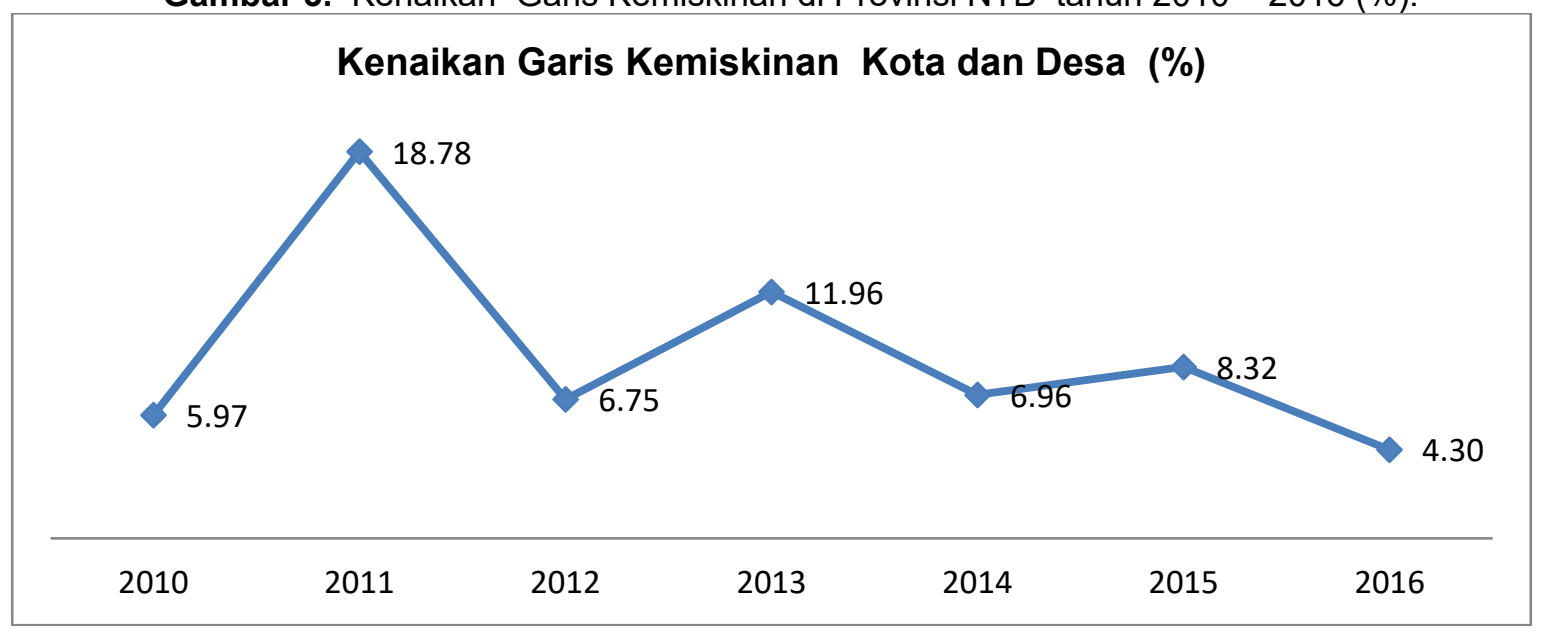

Peningkatan garis kemiskinan tertinggi terjadi pada tahun 2011 sebesar $18,78 \%$ dan terendah pada tahun 2016 sebesar 4,30\%. Pergerakan persentase peningkatan garis kemiskinan di perkotaan dan pedesaan pada tahun 2013 juga berada di ata level $10 \%$ yang mengindikasikan bahwa pada tahun tersebut terjadi gejolak perubahan harga barang jasa yang meningkat. Namun pada tahun 2016 peningkatan garis kemiskinan dengan persentase yang paling rendah, yang bermakna pada tahun tersebut kondisi harga barang relatif lebih baik dibanding tahun - tahun sebelumnya. Peningkatan garis kemiskinan menunjukkan adanya perubahan secara nyata untuk komponen makanan dan bukan makanan baik untuk daerah perkotaan, pedesaan maupun perkotaan dan pedesaan.

Dapat diketahui bahwa selama tahun 2009 -2016 rata-rata persentase garis kemiskinan untuk pemenuhan kebutuhan makanan sebesar 72,99 persen dan 27,01 persen untuk pemenuhan bukan makanan di daerah perkotaan. Untuk daerah pedesaan pemenuhan untuk makanan sebesar 78,24 persen sedangkan untuk pemenuhan kebutuhan bukan makanan sebesar 21,76 persen. Untuk daerah perkotaan dan pedesaan, pemenuhan untuk kebutuhan makanan sebesar 76,01 persen dan pemenuhan untuk kebutuhan bukan makanan sebesar 23, 99 persen. Berdasarkan hal ini, dapat diketahui bahwa bagi penduduk Nusa Tenggara Barat persentase pemenuhan kebutuhan makanan masih jauh lebih tinggi dibandingkan dengan pemenuhan kebutuhan bukan makanan, sehingga masih dapat digolongkan dalam keadaan miskin.

\section{Indeks Kedalaman (P1) dan Keparahan (P2) Kemiskinan}

Kemiskinan penduduk di provinsi Nusa Tenggara dapat ditelusuri juga dari variabel lain yaitu melihat indeks kedalaman dan keparahan kemiskinan (P1 dan P2). Berdasarkan indikator ini dapat diketahui Indeks kedalaman dan keparahan kemiskinan (P1 dan P2) di provinsi Nusa Tenggara Barat tahun 2009 -2016 seperti terlihat dalam tabel berikut. 
Tabel 4.Indeks Kedalaman dan Keparahan Kemiskinan (P1 dan P2) di Provinsi Nusa Tenggara Barat Tahun 2009 -2016.

\begin{tabular}{|l|l|c|c|c|c|c|c|}
\hline \multirow{2}{*}{ No } & \multirow{2}{*}{ Tahun } & \multicolumn{2}{|c|}{ Kota (K) } & \multicolumn{2}{c|}{ Desa (D) } & \multicolumn{2}{c|}{ Kota + Desa } \\
\cline { 3 - 8 } & & P1 & P2 & P1 & P2 & P1 & P2 \\
\hline 1 & 2009 & 7,57 & 2,58 & 3,41 & 0,96 & 5,15 & 1,68 \\
\hline 2 & 2010 & 5,65 & 2,41 & 2,68 & 0,56 & 3,77 & 1,01 \\
\hline 3 & 2011 & 5,122 & 1,56 & 2,056 & 0,402 & 3,335 & 0,885 \\
\hline 4 & 2012 & 4,401 & 1,233 & 2,335 & 0,545 & 3,197 & 0,832 \\
\hline 5 & 2013 & 3,597 & 0,074 & 2,089 & 0,589 & 2,721 & 0,608 \\
\hline 6 & 2014 & 3,897 & 1,102 & 2,217 & 0,448 & 2,922 & 0,722 \\
\hline 7 & 2015 & 2,677 & 0,732 & 2,760 & 0,721 & 2,725 & 0,726 \\
\hline 8 & 2016 & 3,025 & 0,779 & 2,313 & 0,554 & 2,626 & 0,653 \\
\hline
\end{tabular}

Sumber : BPS-NTB

Indeks Kedalaman Kemiskinan (P1) sebagaimana yang terlihat dalam tabel di atas menunjukkan bahwa mengalami fluktuasi dan cenderung menurun. Menurunnya Indeks Kedalaman Kemiskinan (P1) ini menunjukkan bahwa tingkat pengeluaran penduduk miskin memiliki tren atau cendeurung mendekati garis kemiskinan. Hal ini berarti kondisi bahwa kondisi perekonomian penduduk miskin mengalami peningkatan atau berada dalam kondisi yang semakin membaik dari tahun ke tahun. Penurunan Indeks Kedalaman Kemiskinan (P1) di daerah perkotaan menunjukkan keadaan yang selalu lebih besar dibanding dengan daerah pedesaan. Artinya, pengeluaran rata-rata penduduk miskin di daerah perkotaan berada jauh dari garis kemiskinan sementara pengeluaran ratarata penduduk miskin di daerah pedesaan semakin mendekati garis kemiskinan. Hal ini memberikan makna bahwa masyarakat miskin yang berada di daerah perkotaan lebih banyak berada jauh di bawah garis kemiskinan, sebaliknya masyarakat miskin di daerah pedesaan lebih banyak berada di sekitar garis kemiskinan. Dengan demikian bila terjadi gejolak ekonomi, maka penduduk di daerah perkotaan lebih rentan untuk berada di bawah garis kemiskinan dibanding dengan penduduk di daerah pedesaan.
Indeks Keparahan Kemiskinan (P2) sebagaimana yang terlihat pada tabel di atas juga menunjukkan adanya perbedaan yang sangat besar antar penduduk miskin di daerah perkotaan maupun di daerah pedesaan. Menurunnya indeks keparahan kemiskinan (P2) di daerah pedesaan dan berada pada nilai kurang dari 1 menunjukkan bahwa penduduk miskin di daerah pedesaan telah mampu memperbaiki kondisi perekonomiannya serta ketimpangannya tidak terlalu melebar, artinya kesenjangan ekonomi penduduk miskin di daerah pedesaan semakin mengecil. Hal sebaliknya terjadi di daerah perkotaan, meskipun terjadi tren penurunan indeks keparahan kemiskinan (P2) tetapi memenuhi masih lebih tinggi dibanding dengan daerah pedesaan, $\mathrm{Hal}$ ini bermakna bahwa ketimpangan atau kesenjangan ekonomi penduduk miskin di daerah perkotaan masih besar dan melebar. Artinya masih terdapat perbedaan pendapatan yang diperoleh yang berimplikasi pada besarnya ketimpangan pengeluaran yang dilakukan. Dengan demikian kondisi perekonomi penduduk miskin di daerah perkotaan selama priode analisis dapat dikatakan masih belum stabil atau relatif belum menunjukkan pada arah yang lebih baik. 
Secara umum dapat dilihat, bahwa indeks keparahan kemiskinan (P2) untuk daerah perkotaan dan pedesaan menunjukkan kecenderungan menurun dan semakin mendekati titik nol sejak tahun 2009 2016. Hal ini mengindikasikan bahwa ketimpangan pengeluaran penduduk miskin semakin kecil atau semakin menyempit. Hal ini bermakna bahwa penduduk miskin di provinsi Nusa Tenggara Barat telah mengalami pergeseran dalam ketimpangan distribusi pendapatan yang berimplikasi semakin menyempitnya ketimpangan pengeluaran untuk kebutuhan hidupnya baik yang primer maupun sekunder.

\section{Penanganan Kemiskinan Dalam Ekonomi Islam}

Pengentasan kemiskinan dalam agama Islam merupakan suatu keniscayaan, karena berbarengan dengan kehidupan orang kaya. Telah menjadi sunnatullah bahwa miskin dan kaya merupakan suatu realitas dalam kehidupan umat manusia. Keduanya berjalan beriringan dan saling membutuhkan satu sama lain. Meskipun keduanya berbeda dan memiliki karakteristik yang berlainan, namun keduanya saling berdekatan dan saling berjauhan sekaligus. Kedua fenomena itu menggerakkan roda kehidupan ini, yakni mendorong masing - masing manusia untuk saling memberi dan saling menahan (Al-Qubbani, 1999). Al-Qur'an dan AlHadist sebagai pedoman praktek ekonomi Islam, telah memberikan petunjuk kepada umat manusia maupun pelaku - pelaku ekonomi untuk dapat menghindarkan diri, keluarga dan masyarakat dari jeratan kemiskinan. Islam memerintahkan umatnya untuk berusaha melepaskan diri dari jeratan kemiskinan, agar dalam proses kehidupannya dapat berjalan dengan baik untuk mewujudkan kesejahteraan di dunia dan di akherat.

Penanganan kemiskinan dalam Islam dapat dilakukan dengan banyak cara baik yang bersifat tuntutan wajib, sunnah maupun sukarela. Hal - hal yang menjadi tuntutan pengetasan kemiskinan sebagaimana yang diidentifikasi oleh Qardhawi (1995) sebagai berikut: 1) Bekerja; 2) Jaminan sanak famili yang berkelapangan; 3) Zakat; 4) Jaminan
Baitul Mal; 5) Berbagai Kewajiban di luar Zakat; 6) Sedekah Suka Rela dan Kemurahan hati individu. Sementara Arraiyah, (2007) mengungkapkan cara pengentasan kemiskinan adalah sebagai berikut : a) Tuntutan Yang Bersifat Wajib seperti Zakat, Infaq Wajib yang sifatnya Insidental, Menolong orang miskin sebagai ganti kewajiban keagaamaan, Menolong orang miskin sebagai sanksi terhadap suatu pelanggaran hukum agama; b) Tuntutan yang bersifat anjuran seperti : Shadaqah atau Sedekah, Infak, Ihsan dan Qurban ; c) Hak -Hak Khusus bagi Penyandang Kemiskinan yaitu : Hak memperoleh bantuan dari negara, Hak memperoleh ghanimat, Hak memperoleh fa'i dan Hak khusus dalam mengelola harta anak - anak yatim

Cara pengentasan kemiskinan dalam Islam tidak akan terlepas dari aktivitas ekonomi, baik berkenaan langsung dengan penyandang kemiskinan maupun datang dari pihak lain yang tertuju kepada golongan penyandang kemiskinan. Pengentasan kemiskinan dikaitkan dengan aktivitas ekonomi lebih banyak berada pada aktivitas distribusi. Berkenaan dengan hal tersebut, dalam analisis ini pengentasan kemiskinan hanya dilihat dari satu dimensi yaitu dimensi Zakat sebagai tuntutan yang bersifat wajib yang tertuju kepada muzakki.

\section{Penanganan Kemiskinan Melalui Zakat}

Zakat merupakan salah satu solusi untuk mengentaskan penduduk dari jeratan kemiskinan. Hal ini dipertegas oleh Rasulullah bahwa mereka yang berhak menerima zakat hanyalah orang - orang miskin karena tujuan utama zakat adalah untuk menghapuskan kemiskinan. Hal ini diperkuat oleh Abu Hanifah, bahwa zakat tidak boleh diberikan selain kepada orang miskin (Qardhawi, 1999). Zakat merupakan kewajiban yang harus dikeluarkan oleh setiap muslim yang mampu untuk diberikan kepada orang orang yang tidak mampu. Banyak firman Allah yang memerintahkan manusia untuk mengeluarkan hartanya baik dengan berzakat, infaq maupun shadaqah.

Firman - firman Allah tersebut memberi makna bahwa manusia boleh memiliki 
harta, tetapi sesuai dengan kadar dan waktunya harta harus dikeluarkan dalam bentuk yang wajib seperti berzakat. Betapa pentingnya zakat ini sebagai media untuk meningkatkan kualitas kehidupan umat Islam dari kemiskinan. Tedapat sejumlah firman Allah yang menggandengkan dengan sholat. Hal ini menandakan bahwa zakat merupakan bentuk ibadah yang mengandung dua unsur sekaligus yaitu unsur yang menghubungkan manusia sebagai hamba dengan Allah, dan unsur yang menghubungkan manusia dengan sesama manusia bahkan dengan makhluk yang lainnya. Beberapa firman Allah berkenaan dengan hal tersebut terlihat berikut:

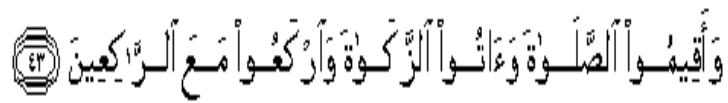

Dan dirikanlah shalat, tunaikanlah zakat dan ruku'lah beserta orang-orang yang rukuk. (Qs. Al-Baqarah 43).

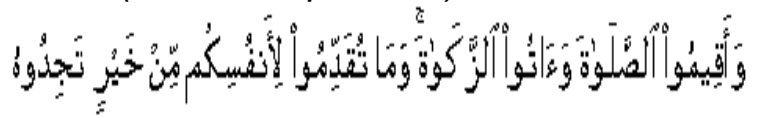

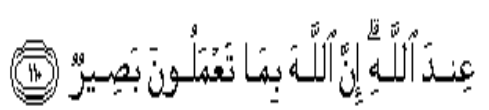

Dan dirikanlah shalat dan tunaikanlah zakat. Dan kebaikan apa saja yang kamu usahakan bagi dirimu, tentu kamu akan mendapat pahala nya pada sisi Allah. Sesungguhnya Alah Maha Melihat apaapa yang kamu kerjakan.

Hadist-hadist yang memerintahkan mengeluarkan zakat dan manfaat serta konsekwensi yang diterima bagi yang mengeluarkan dan enggan mengeluarkan zakat cukup banyak. Beberapa dari hadist tersebut di ambil dua hadist yaitu :

1. Dari Ibnu Umar ra, sesungguhnya Rasulullah SAW telah bersabda : "Aku diperintahkan untuk memerangi manusia sampai ia mengucapkan laa ilaaha illallaah, menegakkan sholat dan mengeluarkan zakat. Barang siapa telah mengucapkannya, maka ia telah memelihara harta dan jiwanya dari aku kecuali dengan alasan yang hak dan kelak perhitungannya terserah kepada Allah Ta'ala (HR. Bukhari- Muslim).

2. Dari Abdirrahman, Abullah bin Umar AlKhattab radhiallahu anhuma berkata : saya mendengar Rasulullah bersabda:
"Islam didirikan di atas lima perkara yaitu bersaksi bahwa tiada sesembahan yang berhak disembah secara benar kecuali Allah dan Muhammad utusan Allah, mendirikan sholat, mengeluarkan zakat, mengerjakan haji ke baitullah dan berpuasa di bulan ramadhan (HR. Bukhari - Muslim).

Dua firman Allah dan dua hadist di atas menegaskan bahwa setelah perintah melaksanakan sholat diikuti oleh perintah mengeluarkan zakat. Kedudukan zakat yang sangat penting ini, akan berdampak pada konsekwensi yang harus diterima bagi orang yang sudah memenuhi syarat untuk mengeluarkan zakat tetapi tidak mengeluarkan zakat. Karena jika tidak mengeluarkan zakat akan mendapat ancaman bahkan ibadah sholatpun akan sia-sia. Berkenaan dengan hal ini Abdullah bin Mas'ud berkata Anda sekalian diperintahkan menegakakan sholat dan membayar zakat. Siapa yang tidak mengeluarkan zakat maka sholatnya tidak akan diterima. Selanjutnya berkata Jabir dari Zaid. " sholat dan zakat adalah kewajiban dalam satu paket, keduanya tidak terpisahkan".

Kemiskinan sebagaimana yang diutarakan oleh Islam harus dilihat dari dua sisi sekaligus, yaitu dari sisi material dan spritual. Kemiskinan materi tampak jelas terlihat dan terukur sementara kemiskinan spritual tampak dan tidak terukur secara kuantitatif, tapi terefleksi dari prilaku dan moral. Zakat memainkan peranan untuk mengentaskan kemiskinan tersebut sekaligus, karena orang yang melaksanakan zakat dapat terlepas dari kemiskinan spritual karena mampu melaksanakan ajaran dan perintah agama. Sisi lain, bagi penerima zakat (mustahik) di samping dapat mengentaskan dirinya dari kemiskinan material sekaligus kemiskinan spritual, karena tidak menjual harga diri dan agamanya untuk mencari kebutuhan hidup yang bersifat materi.

Zakat merupakan gerakan pengentasan kemiskinan yang bersifat wajib (mandatory expenditure) bagi yang tergolong muzakki. Dengan pemahaman agama dan kesadaran yang tinggi, para muzakki mengeluarkkan zakatnya yang 
sudah menjadi kewajiban rutinnya setiap tahun. Menurut Stamboel (2012), dalam sejarahnya, dampak zakat terhadap upaya pengentasan kemiskinan sangat signifikant dan berjalan secara otomatis (built-in) di dalam masyarakat muslim. Hal ini karena peruntukan dan alokasi dana zakat sudah ditentukan secara pasti di dalam ajaran Islam, dimana zakat diperuntukkan hanya pada delapan golongan, dan fakir miskin ditempatkan sebagai kelompok pertama dan kedua dalam daftar penerima zakat.

Zakat sebagai program penanggulangan kemiskinan wajib (mandatory expenditure) dan berjalan otomatis (bulit -in) di dalam Islam karena didasarkan pada dua alasan yaitu (Wibisono, 2015) :

1. Alokasi dana zakat sudah ditentukan secara pasti di dalam syariah (AlQur'an 9 ; 60) yang hanya diperuntukkan bagi delapan golongan (ashnaf) saja. Jumhur ulama sepakat bahwa selain delapan golongan ini, haram menerima zakat. Lebih jauh lagi, al-Qur'an menyebutkan fakir miskin sebagai kelompok pertama dan kedua dalam daftar penerima zakat. Ini menunjukkan bahwa mengatasi masalah kemiskinan merupakan tujuan utama zakat. Karakteristik ini membuat zakat inheren bersifat proo poor dan selftargeted. Tidak satupun instrumen fiskal konvensional yang memiliki karakteristik seperti ini.

2. Zakat dikenakan pada basis yang luas dan meliputi berbagai aktivitas perekonomian. Hal ini menjadi modal dasar yang penting bagi pembiayaan program - program penanggulangan kemiskinan.

3. Zakat merupakan pajak spritual yang wajib dibayar oleh setiap muslim dalam kondisi apapun. Karena itu, penerimaan zakat cenderung stabil. Hal ini akan menjamin keberlanjutan program penanggulangan kemiskinan yang umumnya membutuhkan jangka waktu yang relatif panjang.

Pengentasan kemiskinan di Provinsi Nusa Tenggara Barat dilakukan melalui program-program yang telah direncanakan oleh pemerintah pusat maupun pemerintah daerah dengan berpihak kepada orang miskin (pro poor). Menyadari pentingnya peran zakat dalam mengentaskan kemiskinan, pemerintah provinsi Nusa Tenggara Barat telah menggandeng Badan Amil Zakat Nasional Provinsi (BASNAS-Prov) NTB untuk sama-sama mengentaskan kemiskinan. Baznas-Prov yang dipercayai untuk menghimpun dana zakat dari para muzakki telah berusaha untuk menghimpun dana zakat secara maksimal. Di samping menghimpun zakat, BAZNAS- Prov juga menghimpun dana Infaq dan sedekah yang juga diperuntukkan untuk pendudukpenduduk yang tergolong mustahik maupun yang tidak tergolong mustahik.

Penghimpunan dana yang berasal dari masyarakat terutama Zakat oleh BAZNAS, sebagai implentasi dari tugas BAZNAS sebagai salah satu lembaga keuangan Islam non-bank yang berperan sebagai mediasi dari antara muzakki dengan pihak mustahiq. Para muzakki telah mempercayai sepenuhnya kepada BAZNAS untuk mengelola dan menyalurkan dana zakatnya guna mengubah status kehidupan mustahiq khususnya yang tergolong fakir dan miskin untuk menggapai kehidupan yang lebih baik lagi dari sebelumnya. Kinerja Baznas-Prov dalam menghimpun dana Zakat, Infaq dan Shadaqah (ZIS) terlihat berikut.

Tabel 5. Perkembangan Pengumpulan ZIS BAZNAS NTB Tahun $2012-2016$

\begin{tabular}{|c|c|c|c|}
\hline Tahun & Target (Rp) & Realisasi (Rp) & Persentase (\%) \\
\hline 2012 & 2.000 .000 .000 & 2.254 .000 .000 & 112,70 \\
\hline 2013 & 3.250 .000 .000 & 3.476 .606 .887 & 110,90 \\
\hline 2014 & 5.000 .000 .000 & 5.036 .159 .000 & 110,72 \\
\hline 2015 & 6.500 .000 .000 & 6.679 .291 .148 & 101,20 \\
\hline 2016 & 7.500 .000 .000 & 8.288 .499 .700 & 110,51 \\
\hline
\end{tabular}

Sumber Baznas, NTB, 2017. 
Berdasarkan data di atas dapat terlihat bahwa BAZNAS - Provinsi NTB sesuai dengan potensi ZIS yang ada telah menargetkan penerimaan ZIS yang selalu bertambah dari tahun ke tahun. Kinerja ini sangat menggembirakan, karena setiap tahunnya realisasi dana ZIS yang mampu dihimpun lebih besar dari target yang telah ditentukan. Kondisi ini menunjukkan bahwa kesadaran masyarakat untuk mengeluarkan ZIS dari tahun ke tahun mengalami peningkatan, dan tingkat kepercayaan terhadap Baznas sebagai lembaga pengelola ZIS semakin tinggi. Hal ini idisebabkan salah satunya adalah para muzakki telah melihat adanya perubahan kehidupan masyarakat baik dilihat pemenuhan kebutuhan pokok maupun kesempatan untuk membuka lapangan kerja baru.

Realisasi penghimpunan ZIS yang selalu meningkat menggambarkan bahwa Baznas - Provinsi NTB telah melakukan usaha maksimal untuk menghimbau para muzakki maupun masyarakat umumnya untuk menyalurkan ZIS melalui lembaga resmi yang telah dibentuk oleh pemerintah. Namun dilihat secara persentase, realisasi yang selalu melebihi 100 persen, mengalami penurunan dari tahun 2012 - 2015, tetapi pada tahun 2016 relaisasi kembali meningkat mencapai $110,51 \%$ Hal ini mengindikasikan adanya permasalahan baru yang muncul dalam proses pengelolaan dana ZIS yang dilakukan oleh Baznas- Provinsi NTB.

Peranan zakat dalam mengentaskan kemiskinan di NTB telah memberikan hasil, setidaknya menurunnya persentase penduduk miskin dari tahun ke tahun telah menunjukkan bahwa zakat telah berkontribusi di dalamnya. Penggunaan dana zakat diberikan kepada delapan golongan (ashnaf) tidak hanya dengan memberikan uang secara gratis dan habis dipakai untuk memenuhi kebutuhan hidup. Penyaluran dana juga diperuntukkan untuk memfasilitasi pengembangan sekolah - sekolah maupun untuk biaya pendidikan anak anak penduduk yang tergolong miskin mulai dari jenjang sekolah dasar sampai perguruan tinggi.
Zakat sebagai kewajiban bagi penduduk yang tergolong muzakki merupakan ajaran Islam yang mencegah terjadinya penumpukan harta pada orang - perorang atau golongan. Zakat mampu menjadi sarana yang menciptakan keadilan ekonomi, serta adanya sikap saling memberi dari pihak yang punya kepada pihak yang membutuhkan. Zakat merupakan perwujudan riel terciptanya jaminan sosial di dalam Islam. Abdul Manan yang dikutip oleh Huda, dkk (2015) mengatakan bahwa fungsi zakat meliputi bidang moral, sosial dan ekonomi. Dalam bidang moral zakat mengikis ketamakan dan keserakahan si kaya. Adapun dalam bidang sosial, zakat berfungsi menghapuskan kemiskinan dari masyarakat. Di bidang ekonomi, zakat mencegah penumpukan kekayaan di tangan sebagian kecil manusia dan merupakan sumbangan wajib kaum muslimin untuk perbendaharaan negara.

Zuhaily sebagaimana yang dikutip oleh Hafidhuddin (2002) mengatakan bahwa tujuan zakat dari sudut pembangunan kesejahteraan masyarakat memiliki tujuan yang sangat mulia yaitu : 1) Menggalang jiwa dan semangat untuk menunjang dan solidaritas sosial di kalangan masyarakat Islam; 2) Merapatkan dan mendekatkan jarak dan kesenjangan sosial ekonomi masyarakat; 3) Menanggulangi pembiayaan yang mungkin timbul akibat berbagai macam bencana seperti bencana alam maupun bencana lainnya.; 4) Menutup biaya - biaya yang timbul akibat terjadinya konflik, persengketaan dan berbagai bentuk kekerasan dalam masyarakat; 5) Menyediakan suatu dana taktis dan khusus untuk penanggulangan biaya hidup para gelandangan, para pengangguran dan tunasosial lainnya, termasuk dana untuk membantu orang orang yang hendak menikah tetapi tidak memiliki dana untuk itu.

Berdasarkan tujuan dan fungsi zakat yang telah diuraikan di atas, jelaslah bahwa pengentasan kemiskinan tidak dapat dilakukan hanya semata-mata mengandalkan kebijakan serta dana dana dari pemerintah. Umat Islam telah memiliki sumber dana abadi yang berfungsi untuk menuntaskan kemiskinan yang bermuara pada peningkatan kualitas 
hidup umat Islam. Kualitas hidup yang baik, ditunjang oleh kesempatan untuk memperoleh keadilan, kenyamanan dan keamanan, maka umat Islam akan mampu menggapai kesejahteraan baik secara material maupun spritual. Hal inilah yang mendasari diperintahkannya kewajiban zakat serta untuk menciptakan suasana saling menghargai, mengisi, memberi dan menjaga antara muzakkii dengan para mustahik.

Islam mengajarkan kepada umat manusia untuk melakukan kepekaan sosial melalui distribusi harta baik secara wajib maupun sukarela yaitu dalam bentuk Zakat, Infaq, Shadaqah, tidak hanya bertujuan untuk menghilangkan kemiskinan melainkan juga untuk meningkatkan kepedulian sosial dan keharmonisan (Ahmad, 1998). Hal ini mengandung makna, bahwa dengan terjadinya distribusi harta dari orang yang mampu kepada orang yang tidak mampu, akan tercipta suasasa hidup yang penuh dengan kebersamaan dan kekeluargaan, sehingga tercipta suasana kedamaian, kenyaman dan keharmonisan dalam menata kehidupan. Dengan demikian, penanganan dan pengentasan kemiskinan melalui distribusi harta telah menimbulkan manfaat bagi kedua belah pihak baik yang tergolong mampu (kaya) dengan yang tergolong tidak mampu (miskin).

Zakat sebagai ibadah wajib maupun infaq, sedekah dan lainnya sebagai ibadah sunah diharapkan akan memberikan kontribusi yang cukup berarti dalam upaya mengangkat harkat dan martabat kaum fakir maupun miskin. Zakat harus mampu menjadi instrumen utama dalam sistem ekonomi Islam sebagai sumber keuangan yang permanen dalam mengentaskan kemiskinan. Oleh karenanya, Zakat maupun Infaq dan Shadaqah serta sumber - sumber keuangan lainnya sebaiknya harus dikelola oleh pemerintah. Hal ini sesuai dengan perintah dalam Al-Qur'an sebagaiamana firman Allah dalam surat At-Taubah 103.

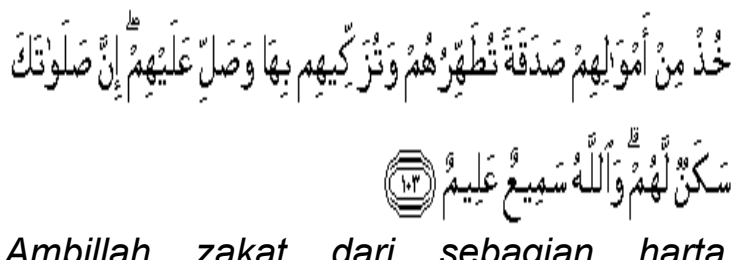

Ambillah zakat dari sebagian harta mereka, dengan zakat itu kamu membersihkan dan mensucikan mereka dan mendoalah untuk mereka. Sesungguhnya doa kamu itu (menjadi) ketenteraman jiwa bagi mereka. Dan Allah Maha Mendengar lagi Maha Mengetahui.

Menurut para mufassirin, perintah Ambillah zakat adalah pemerintah atau negara yang harus mengelola dana yang diperoleh dari zakat. Menurut Ali (2006), ada beberapa alasan pengelolaan Zakat harus dilalukan oleh pemerintah yaitu : 1) Zakat bukanlah bentu charity biasa atau betuk kedermawanan sebagaimana infaq, wakaf dan hibah. Zakat hukumnya wajib (imperatif) sementara charity atau donasi hukumnya mandub (sunah); 2) Potensi zakat yang dikumpulkan dari masyarakat Indonesia sangat besar; 3) Zakat mempunyai potensi untuk turut membantu pencapaian sasaran pembangunan nasional; 4) Agar dana zakat dapat disalurkan secara tepat, efisien dan efektif sehingga mencapai tujuan zakat itu sendiri seperti meningkatkan taraf hidup masyarakat; 5) Memberikan kontrol kepada pengelola negara.

Keterlibatan negara dalam mengelola dana zakat dengan membentuk BAZNAS, menunjukkan negara memiliki harapan besar dari dana zakat sebagai sumber pendapatan negara. Perjalanan BAZNAS telah mengalami perkembangan meskipun diterpa berbagai tantangan berkenaan dengan masih besarnya potensi yang belum mampu dikumpulkan sebagai sumber zakat yang permanen. Adanya kerja sama BAZNAS sebagai lembaga dan masyarakat wajib zakat (mujakki) akan membawa sinergi yang baik dalam ikhtiar mewujudkan dana zakat sebagai sumber keuangan islam yang utama.

\section{Faktor-Faktor Penyebab Kemiskinan}

Faktor-faktor penyebab kemiskinan dalam ekonomi Islam juga telah diidentifikasi oleh pakar - pakar ekonomi Islam. Faktorfaktor penyebab kemiskinan dalam ekonomi Islam dapat dilihat dari perilaku 
manusia dalam memanfaatkan dan mengelola sumber daya yang tersedia. Wibisono (2015) menyatakan dalam AlQur'an terdapat beberapa faktor struktural yang menyebabkan kemiskinan yaitu ;

1. Kemiskinan karena kejahatan manusia terhadap alam (QS. $30 ; 41$ ) sehingga manusia itu sendiri yang merasakan dampaknya (QS. $42: 30$ )

2. Kemiskinan timbul karena ketidakpedulian dan kebakhilan kelompok kaya (QS 3 ; 180, QS ; 70 : 18) sehingga si miskin tidak mampu keluar dari lingkaran kemiskinan;

3. Kemiskinan timbul karena sebagian manusia bersikap zhalim, eksploitatif, dan menindas kepada sebagian manusia yang lain, seperti memakan harta orang lain dengan jalan bathil (QS 9 ; 34), memakan harta anak yatim (QS $4: 2,6,10$ ), dan memakan harta riba (QS 2 ; 275).

4. Kemiskinan timbul karena konsentrasi kekuatan politik, birokrasi dan ekonomi di satu tangan.

5. Kemiskinan timbul karena gejolak ekternal seperti bencana alam (QS 34 : 14 - 15) dan peperangan sehingga negeri yang semula kaya berubah menjadi miskin (QS $59 ; 8-9$ ).

Qardhawi (2005) mengatakan bahwa mengentaskan kemiskinan harus sekaligus mengentaskan faktor -faktor penyebab timbulnya kemiskinan tersebut. Faktor - faktor penyebab kemiskinan adalah : 1) Kemiskinan disebabkan oleh kelemahan fisik yang menjadi penghalang dirinya dalam mendapatkan penghasilan yang besar; 2) Kemiskinan yang disebabkan oleh ketidakmampuan untuk mencari pekerjaan, karena ditutupnya pintu - pintu pekerjaan yang halal sesuai dengan keadaan para fakir miskin tersebut; 3) Kemiskinan yang disebabkan oleh tidak cukupnya penghasilan yang diperoleh untuk memenuhi kebutuhannya dan ketidamampuan untuk mewujudkan kecukupan, spertinya para buruh dan petani, pekerja rendahan ataupun wiraswasta.

\section{KESIMPULAN DAN SARAN}

\section{Kesimpulan}

Berdasarkan hasil analisis dan pembahasan berdasarkan tujuan penelitian, maka dapat dibuat kesimpulan sebagai berikut.

1. Jumlah penduduk miskin di Pulau Lombok sebanyak 72,81 persen dengan jumlah penduduk miskin terbanyak di Kabupaten Lombok Timur sebanyak 216.180 jiwa pada bulan Maret tahun 2016. Sedangkan yang berada di Pulau Sumbawa sebesar 27,19 persen., dengan jumlah penduduk miskin terbanyak di Kabupaten Bima sebanyak 72.360 jiwa pada bulan Maret tahun 2016.

2. Persentase Penduduk Miskin di Nusa Tenggara Barat mengalami penurunan dari 22,78 persen pada tahun 2009 menjadi 16,02 persen pada tahun 2016. Kondisi ini masih lebih tinggi dbandingkan dengan persentase penduduk miskin secara nasional sebesar 14,4 persen tahun 2009 dan 10,64 persen tahun 2016. Selama kurun waktu 2009 - 2016 persentase penduduk miskin menurun sebanyak 6,76 persen atau rata - rata 0,85 persen per tahun.

3. Jumlah penduduk miskin berdasarkan daerah menunjukkan kemiskinan di daerah pedesaan masih lebih tinggi dibanding daerah perkotaan. Jumlah penduduk miskin di daerah pedesaan pada tahun 2009 sebanyak 493.409 jiwa pada tahun 2009, turun menjadi sebanyak 407.750 jiwa pada tahun 2016. Sedangkan di daerah perkotaan sebanyak 557.539 jiwa pada tahun 2009 turun menjadi 378.830 jiwa pada tahun 2016.

4. Secara persentase, penduduk miskin di daerah pedesaan sebesar 18,40 persen pada tahun 2009 menjadi 14,82 persen pada tahun 2016, sedangkan di daerah perkotaan sebesar 28,84 persen pada tahun 2009 menjadi 17,55 persen pada tahun 2016.

5. Garis kemiskinan yang ditetapkan oleh BPS untuk penduduk miskin di daerah perkotaan sebesar $\mathrm{Rp}$ 213.450,- meningkat menjadi $\mathrm{Rp}$ 
346.581,- yang terdiri dari $\mathrm{Rp}$. 252.343,- tahun 2016. Sedangkan untuk di daerah pedesaan sebesar Rp 164.526,- tahun 2009, meningkat menjadi Rp 328.775,- tahun 2016. Pengeluaran untuk makanan masih lebih besar dibanding pengeluaran non makanan baik untuk daerah perkotaan maupun pedesaan.

6. Indeks Kedalaman (P1) kemiskinan di NTB pada tahun 2009 sebesar 5,15 mengalami penurunan menjadi 2,626 pada tahun 2016 . Hal ini menunjukkan bahwa kondisi perekonomian penduduk miskin mengalami peningkatan atau berada dalam kondisi yang membaik. Indeks Keparahan Kemiskinan (P2) di NTB pada tahun 2009 sebesar 1,68 pada tahun 2009t turun menjadi 0,653 pada tahun 2016. Hal ini menunjukkan bahwa ketimpangan pengeluaran penduduk miskin semakin kecil atau semakin menyempit. Artinya penduduk miskin di NTB telah mengalami pergeseran dalam ketimpangan pendapatan.

7. Pengentasan kemiskinan dalam ekonomi Islam mengacu pada AlQur'an dan Al- Hadist. Pengentasan kemiskinan dalam Islam dapat dilakukan dengan beberapa cara, baik perintah wajib, anjuran maupun sukarela. Salah satu cara pengentasan kemiskinan dalam Islam adalah melalui perintah kewajiban mengeluarkan zakat baik zakat fitrah maupun zakat harta. Zakat merupakan gerakan pengentasan kemiskinan yang bersifat wajib (mandatory expenditure) bagi yang tergolong muzakki. Dampaknya berpengaruh secara signifikan dan bersifat otomatis (built-in) di dalam masyarakat muslim.

8. Baznas Provinsi Nusa Tenggara Barat telah mampu menghimpun dana Zakat, Infaq dan shadaqah (ZIS) dan berkontribusi dalam pengentasan kemiskinan di Nusa Tenggara Barat. Jumlah dana ZIS yang berhasil dihimpun pada tahun 2012 sebesar Rp 2.254.000.000,- melebih target yang ditetapkan Rp 2.000.000.000,-Kondisi tahun 2016 mencapai Rp 8.288.499.700,- dari target sebesar Rp 7.500.000.000,-. Dana yang dihimpun ini telah disalurkan kepada mustahiq dan penerima lainnya dalam berbagai bentuk yang tujuannya untuk meningkatkan kualitas hidup mustahik dari keadaan sebelumnya.

\section{Saran}

1. Pemerintah Daerah Provinsi Nusa Tenggara Barat kiranya terus berikhtiar untuk terus melaksanakan kebijakan - kebijakan yang berkaitan dengan pengentasan penduduk miskin sesuai dengan target yang ditetapkan, setidaknya bisa mendekati 1,5-2 persen per tahun.

2. Ketimpangan ekonomi dan kondisi perekonomian penduduk miskin yang telah dicapai sekarang dapat ditingkatkan dengan tetap memberikan perhatian bagi penduduk miskin untuk dapat meningkatkan pendapatan dan pengelurannya jauh dari garis kemiskinan.

3. BAZNAS Provinsi Nusa Tenggara Barat hendaknya terus berusaha untuk meningkatkan penghimpunan dana ZIS dari masyarakat dengan melakukan sosialisasi sekaligus mendatangi secara langsung para muzakki yang belum mengumpulkan zakatnya melalui BAZNAS.

4. Diperlukan langkah - langkah strategis bagi BAZNAS untuk mampu menggali potensi zakat yang belum mampu di sentuh terutama para petani, pedagang dan profesi lainnya di luar Pegawai Negeri Sipil (PNS). 


\section{DAFTAR PUSTAKA}

Abd. Majid, M.Shabri, 2011. Mengentaskan Kemiskinan Dalam Ekonomi Syariah. Jurnal Ekonomi dan Keuangan Islam, Volum 1 No 2, Juli 2011/Sya'ban 1432, Hal 197-205.

Ali, Nuruddin Mhd, 2006, Zakat Sebagai Instrumen Dalam Kebijakan Fiskal, PT. RadjaGrafindo Persada, Jakarta.

Al-Qubbani, M. Bahauddin, 1999. Miskin dan Kaya Dalam Pandangan Al-Qur'an, Gema Insani, Jakarta.

Arraiyah, M. Hamdar, 2007. Meneropong Fenomena Kemiskinan Telaah Prespektif AlQur'an Pustaka Pelajar, Yogyakarta.

Arsyad, Lincolin, 2010. Ekonomi Pembangunan, UPP STIM YKPN, Yogyakarta.

Badan Pusat Statistik NTB, 2017. Profil Kemiskinan di Nusa Tenggara Barat 2009 - 2016. Mataram. Berita Resmi Statistik, September 2009 - 2016.

Badruddin, Rudy, 2012. Ekonomika Otonomi Daerah, UPP STIM YKPN, Yogyakarta.

Badan Amil Zakat Nasional (BAZNAS) NTB, 2017, Perkembangan Pengumpulan ZIS BAZNAS Provinsi NTB 2012 - 2016, Mataram.

Maipita, Indra, 2014. Mengukur Kemiskinan dan Distribusi Pendapatan., UPP STIM YKPN Yogyakarta.

Qardhawi, Yusuf, 1995. Kiat Islam Mengentaskan Kemiskinan, Gema Insani Press, Jakarta.

,2005, Spektrum Zakat Dalam Membangun Ekonomi Kerakyatan, ZIKRUL HAKIM, Jakarta.

Ibrahim, Saad, 2007. Kemiskinan Dalam Prespektif AI-Qur'an, U-Mlang Press.

Setiadi, Elly M dan Usman Kolip, 2011. Pengantar Sosiologi Pemahaman Fakta dan Gejala Permasalahan Sosial : Teori, Aplikasi dan Pemecahannya. Kencana, Jakarta.

Stamboel, Kemal A., 2012. Panggilan Keberpihakan, Strategi Mengakhiri Kemiskinan di Indonesia PT. Gramedia Pustaka Utama, Jakarta.

Sumodiningrat, Gunawan dan Ari Wulandari, 2015. Menuju Ekonomi Berdikari Pemberdayaan UMKM Dengan Konsep OPOP (One Person One Product) - OVOP (One Village One Product) - OVOC (One Village One Corporation). Media Pressindo, Yogyakarta.

Wargadinata, Wildana, 2011, Islam dan Pengentasan Kemiskinan, UIN-MALIKI Press, Malang.

Wibisono, Yusuf, 2015. Mengelola Zakat di Indonesia Diskursus Pengelolaan Zakat Nasional dari Rezim Undang - Undang Nomor 38 Tahun 1999 ke Rezim Undang Undang Nomir 23 Tahun 2011, PrenadaMedia Group, Jakarta.

Widodo, Susno Triyanto, 1990, Indikator Ekonomi Dasar Perhiyungan Perekonomian Indonesia. 